\title{
Fifty Years of Research on European Mink Mustela lutreola L., 1761 Genetics: Where Are We Now in Studies on One of the Most Endangered Mammals?
}

\author{
Jakub Skorupski ${ }^{1,2}$ \\ 1 Institute of Marine and Environmental Sciences, University of Szczecin, Adama Mickiewicza 16 St., \\ 70-383 Szczecin, Poland; jakub.skorupski@usz.edu.pl; Tel.: +48-914-441-685 \\ 2 Polish Society for Conservation Genetics LUTREOLA, Maciejkowa 21 St., 71-784 Szczecin, Poland
}

Received: 2 October 2020; Accepted: 6 November 2020; Published: 11 November 2020

\begin{abstract}
The purpose of this review is to present the current state of knowledge about the genetics of European mink Mustela lutreola L., 1761, which is one of the most endangered mammalian species in the world. This article provides a comprehensive description of the studies undertaken over the last 50 years in terms of cytogenetics, molecular genetics, genomics (including mitogenomics), population genetics of wild populations and captive stocks, phylogenetics, phylogeography, and applied genetics (including identification by genetic methods, molecular ecology, and conservation genetics). An extensive and up-to-date review and critical analysis of the available specialist literature on the topic is provided, with special reference to conservation genetics. Unresolved issues are also described, such as the standard karyotype, systematic position, and whole-genome sequencing, and hotly debated issues are addressed, like the origin of the Southwestern population of the European mink and management approaches of the most distinct populations of the species. Finally, the most urgent directions of future research, based on the research questions arising from completed studies and the implementation of conservation measures to save and restore M. lutreola populations, are outlined. The importance of the popularization of research topics related to European mink genetics among scientists is highlighted.
\end{abstract}

Keywords: conservation genetics; cytogenetics; endangered species; genetic markers; genomics; mitogenomics; Mustela sp.; Mustelidae; phylogenetics; population genetics

\section{Introduction}

Due to ongoing population depletion, both in terms of the actual number of individuals and area occupied, European mink Mustela lutreola L., 1761 is considered one of the most endangered mammalian species in the world $[1,2]$. The species was originally spread over most of continental Europe, but nowadays only three wild, isolated, declining populations occupying less than $3 \%$ of the former range survive [3]. About 5000 individuals are estimated to persist in the wild [3]. Reintroduced populations were established in Estonia and Germany [2]. The main cause of the situation of this species is habitat loss and fragmentation, overhunting, and the effects of introduced invasive American mink Neovison vison [4]. The alarming situation of the species is proven by its categorization as critically endangered (CR) by the International Union for Conservation of Nature (IUCN) Red List of Threatened Species, and it is listed in Annex II to the Bern Convention on the Conservation of European Wildlife and Natural Habitats, Annexes II and IV (priority species) of the Council Directive 92/43/EEC on the conservation of natural habitats and of wild fauna and flora, and in The Carpathian List of Endangered Species (critically endangered species (CR)) [2,5]. 
Despite this, the number of studies on European mink, reflected in the number of scientific papers devoted to the species, is relatively low. The digital repository of the National Centre for Biotechnology Information (NCBI) records less than 60 scientific articles devoted to various aspects of the biology of the species. In comparison, the same repository lists as many as 2000 articles related to the giant panda Ailuropoda melanoleuca [6]. Studies in the field of genetics of M. lutreola are limited and urgently need to be completed, especially in the context of the progressing extinction process and the disappearance of its numerous populations in France, Belarus, and Russia, among others [2]. Among the scientific articles devoted to the species and recorded in the NCBI repository, only $\sim 15$ concern genetic issues (not including multispecies phylogenetic analyses not directly focused on European mink) [6]. The rapidly shrinking and vanishing genetic resources will largely never be studied and described, which is an irreversible loss from cognitive and practical points of view $[7,8]$. The meagre data on interpopulation genetic diversity may significantly impair the efficacy of the implemented activities for restitution of the European mink, especially in the context of conservation breeding and species reintroduction [7,9-12].

Notably, only (conservation) genetics can provide tools to rescue species affected by the extinction vortex [13], which, in turn, requires more research initiatives in the conservation genetics of the European mink [14,15].

The pioneer genetic studies on European mink concerning cytogenetics were conducted in the former USSR. To date, works by Volobuev and Ternovsky [16], Volobuev et al. [17], Graphodatsky et al. [18], Graphodatsky et al. [19], and Graphodatsky and Radjabli [20], strongly affiliated with the Siberian Branch of the Russian Academy of Sciences in Novosibirsk (Russia), are the primary sources of information on M. lutreola karyotype. Further research on the genetics of European mink relates primarily to genetic markers $[9,21]$, the phylogenetic relationships of the species [22-26], noninvasive methods of identification [27], assessment of intraspecies genetic diversity $[8,14,28-30]$, and mitochondrial DNA (mtDNA) studies [24,28,31,32]. Worth mentioning are studies concerning molecular ecology on issues relating to European mink and implementing genetic research methods [33-36].

The purpose of this review was to present the current state of knowledge about the genetics of European mink, with particular emphasis on the possibility of its practical application in species conservation. The case of M. lutreola provides a good example of the possibility of achieving the goal of conservation genetics, i.e., applying genetic knowledge and methods to preserve endangered species, as well as to support evidence-informed conservation activities and strategies based on knowledge about the current state of the species' genetic resources [32,37].

The added value of this review article is an extensive and up-to-date review of the available specialist literature on the genetics of European mink, including an update detailing in terms of genetics, the species bibliography published by Youngman [38]. The review not only includes articles published in scientific journals and books, but also in scientific conference reports, Ph.D. theses, and websites of research and nature conservation institutions. For the phylogeographic and demographic studies, only those focused on population genetics of contemporary populations and reasons for their current geographical distribution are included in this review.

Additionally, a definition of conservation (captive) breeding genetics is formulated.

\section{Cytogenetics}

The diploid number of the chromosomes of European mink is 38 , which is typical for many species of the Mustelidae Fischer, 1817 family; for more than $60 \%$ of species of this group, $2 n=38[39,40]$. Among the representatives of the Mustela L., 1758 genus, the diploid number of chromosomes ranges from 38 to 44 [41,42]. Significantly, in the case of American mink, $2 n=30$, which, on a cytogenetic basis, additionally indicates a relatively low degree of its evolutionary relationship with European mink [43].

The chromosomal set of $M$. lutreola consists of five pairs of metacentric chromosomes of different sizes, two pairs of subtelocentric chromosomes, five pairs of submetacentric chromosomes, and seven 
pairs of telocentric chromosomes [16]. The $X$ chromosome is submetacentric, while the $Y$ chromosome is metacentric [18]. As with other representatives of the Mustelidae family, the Y chromosome is the smallest one [40]. The fundamental number (FN, number of chromosomal arms) is 62, while the fundamental autosomal number ( $F N a$, number of autosomal arms) is 58 [16]. Nucleolus organizer regions (NORs) were identified in one pair of telocentric chromosomes [16]. The standard pattern of European mink karyotype is not currently established [40].

The characteristics of the $\mathrm{G}$ and $\mathrm{C}$ bands of chromosomes of European mink were presented by Graphodatsky et al. $[18,19,44]$. The pattern of the Ag-NOR bands, obtained by silvering the nucleolar organizer regions, was also described [20]. A detailed comparison of the patterns of $G$ bands of chromosomes of European mink, American mink, least weasel Mustela nivalis, mountain weasel Mustela altaica, Japanese marten Martes melampus, European badger Meles meles, and striped polecat Ictonyx striatus was presented by Graphodatsky et al. [44]. In terms of the G-band pattern and chromosomal number, size, and morphology, European mink shows many similarities with the Siberian weasel Mustela sibirica [18,23].

\section{Genetic Markers}

The best-known genetic markers of European mink are the microsatellite nuclear sequences (short tandem repeats (STRs) and simple sequence repeats (SSRs)), which are sequential patterns of DNA consisting of several nucleotides and tandem repeats [21]. They are used in phylogenetic studies and analyses of intra- and interpopulation genetic variation and internal genetic structure for detection of evolutionary events in phylogenesis of European mink, phylogeographic reconstructions, and potentially identification of interspecies M. lutreola $\times$ Mustela putorius hybrids $[9,30,45-47]$. The names of microsatellite markers of European mink consist of a unique number preceded by the abbreviation "Mlut". Cabria et al. [9] identified eight unique microsatellite loci of M. lutreola, which are listed in Table 1.

Table 1. Microsatellite loci identified for Mustela lutreola by Cabria et al. [9].

\begin{tabular}{cccc}
\hline Microsatellite Loci & $\begin{array}{c}\text { GenBank } \\
\text { Accession Code }\end{array}$ & Repetitive Motif & $\begin{array}{c}\text { Number of Alleles } \\
\text { Identified }\end{array}$ \\
\hline Mlut04 & EF093582 & $(\mathrm{GT})_{16}$ & 5 \\
Mlut08 & EF093583 & $(\mathrm{GT})_{12}$ & 4 \\
Mlut15 & EF093585 & $(\mathrm{GT})_{14}$ & 5 \\
Mlut20 & EF093587 & $(\mathrm{GT})_{18}$ & 8 \\
Mlut25 & EF093588 & $(\mathrm{GT})_{15}$ & 6 \\
Mlut27 & EF093589 & $(\mathrm{GT})_{8} \mathrm{NN}(\mathrm{GT})_{14}$ & 2 \\
Mlut32 & EF093590 & $(\mathrm{GT})_{59}$ & 8 \\
Mlut35 & EF093591 & $(\mathrm{GT})_{15} \mathrm{NNNN}(\mathrm{GT})_{4} \mathrm{NN}(\mathrm{GT})_{7}$ & 4 \\
\hline
\end{tabular}

Microsatellite markers of European mink were successfully amplified in other species of the Mustelidae family, including in Mustela eversmanii, Mustela putorius furo, M. sibirica, M. nivalis, N. vison, Mustela erminea, Martes martes, and Martes foina, among others [9,48], demonstrating the possibility of using of the STR markers of M. lutreola in studies on genomes of other mustelids. In turn, Peltier and Lodé [45], Michaux et al. [8], Lodé et al. [49], and Cabria et al. [30] positively assessed the possibility of using starter sequences developed for amplification of microsatellites in the genome of other species of the Mustelidae family for studies on the population genetics, phylogenetics, and phylogeography of European mink (Table 2).

Besides the polymorphism of neutral genetic markers, variants of allozymes and the $d r b$ gene from the family of genes of major histocompatibility complex (MHC) class II were analyzed in M. Iutreola [49-52]. Of 36 allozyme loci of European mink analyzed by Lodé et al. [49], two allelic forms were determined for only four of them (the gene for carboxylesterase/EC 3.1.1.1, est-2; the gene for NADP-dependent cytosolic malate dehydrogenase/EC 1.1.1.40, me-1; the gene for 
malate dehydrogenase (MDH)/EC 1.1.1.37, $m d h-1$; and the gene for nonspecific protein). All other loci were monomorphic, whereas for samples analyzed in parallel from the European polecat, nine polymorphic loci were found [49]. For the $d r b$ gene, Becker et al. [50] described nine allelic forms. Nishita et al. [51,52] conducted phylogenetic analyses based on the sequence of the second exon of the $d r b$ gene, demonstrating the evolutionary closeness of this sequence in M. sibirica, Mustela itasi, and M. lutreola and its trans-species polymorphism (TSP), indirectly evidencing selection balance.

Table 2. Microsatellite loci identified for M. lutreola by Cabria et al. [9].

\begin{tabular}{lcc}
\hline \multicolumn{1}{c}{ Species } & Microsatellite Loci & Reference \\
\hline American mink & $\begin{array}{c}\text { Mvi002, Mvi020, Mvi022, Mvi054, Mvi072, } \\
\text { Mvi075, Mvi111, Mvi389, Mvi1843 }\end{array}$ & $\begin{array}{c}\text { Michaux et al. [8], Cabria et al. [30], } \\
\text { Peltier and Lodé [45], Lodé et al. [49] }\end{array}$ \\
\hline European polecat & PutFK1 & Peltier and Lodé [45] \\
\hline Stoat & Mer009, Mer022, Mer041 & Michaux et al. [8], Cabria et al. [30] \\
\hline
\end{tabular}

\section{Genomics}

The genome of European mink has not yet been sequenced. However, Mouton et al. [53] reported the first attempt of whole genome sequencing (30x) of one individual from the Charente-Maritime region (Southwestern France) to perform a genome scan for runs of homozygosity ( $\mathrm{ROH}$ ) to estimate inbreeding, as well as to investigate recent demographic events on the basis of genomic data.

For the species, 160 nucleotide sequences (DNA and RNA) were deposited in GenBank [54]. This number includes the complete sequence of the nuclear gene for the angiotensin-I-converting enzyme 2 (ACE2) of $4097 \mathrm{bp}, 61$ records for mtDNA, 30 of which represent haplotypes of the cytb gene ( 26 for fragments of 337 to $504 \mathrm{bp}$ and four for the complete gene sequence of $1140 \mathrm{bp}$ ), 23 haplotypes for the control region ( 357 to $990 \mathrm{bp}$ ), and the whole mitogenome sequence. In comparison, 357,611 and 19,698 records of the nucleotide sequences of M. putorius and M. putorius furo [54] and N. vison were deposited in GenBank, respectively.

Lushnikova et al.'s [55] work can be considered the first genomic research on European mink. Their studies concerned DNA reassociation kinetics, revealing the share of the genomic DNA fraction representing repetitive sequences in the species genome. The genome size of $M$. lutreola was estimated at $6.4 \mathrm{pg}$, and the shares of rapidly (representing highly repetitive DNA sequences), intermediately (representing moderately repetitive sequences), and slowly- (representing low-repetitive, complex, and unique DNA sequences) renaturing fractions were shown to be $17 \%, 13 \%$, and $70 \%$, respectively [55]. In the same study, differences in DNA quantity and heterochromatin amount were found between European mink, American mink, and marbled polecat Vormela peregusna [55]. The most variable component in the mentioned species is the moderately repetitive genome component [55].

Pioneering studies on the genome scale included comparative studies concerning RFLP-EcoRI and RFLP-BamHI polymorphisms in M. lutreola, M. putorius, N. vision, M. erminea, M. sibirica, and V. peregusna [56]. The obtained digest patterns demonstrated interspecific variation in length and the number of a repeated sequences copies. In European mink, the identified $0.7 \mathrm{~kb}$ EcoRI repeats were dispersed over karyotype, the $1.9 \mathrm{~kb} B a m \mathrm{HI}$ repeats were concentrated in the heterochromatic pericentromeric regions and additional chromosome arms, while the $1.35 \mathrm{~kb} B a m \mathrm{HI}$ repeats were only located in the centromeric regions [56]. The BamHI repeats (interspecific variability of DNA-DNA hybridization patterns) were also applied to consider the phylogenetic relationships of the abovementioned species, indicating existence of a common evolutionary group including M. lutreola, M. sibirica, and M. putorius [57].

Due to its high cytogenetic similarity and proven close phylogenetic relationships [22,24,34,42], the size of the nuclear genome of European mink can be estimated on the basis of the sequenced genome of the ferret (MusPutFur1.0, RefSeq assembly accession: GCF_000215625.1) and M. putorius (polecat_10x_lmp_bionano, GenBank assembly accession: GCA_902207235.1) as being about 
2.411-2.474 million bp, the content of GC pairs as about $42 \%$, and the number of genes as about $27,300[58]$.

The complete reference mitochondrial genome of European mink was sequenced de novo in 2017 (GenBank accession code: MT304869), with the length of nucleotide sequence being 16,523 bp [32]. The comparison of the recognized sequence of mitogenome of $M$. lutreola with the complete sequences of mitochondrial genomes of 24 Mustelidae species deposited in GenBank and conducted in BLAST [59] showed a similarity at the level of $86-99 \%$ (Table 3). The phylogenetic analysis conducted on the basis of the recognized sequence of $M$. lutreola mtDNA indicated its high affinity with European polecat (and ferret) and its explicit presence in the clade including M. eversmanni, Mustela nigripes, $M$. sibirica, and M. itatsi [60]. Comparison of the mitogenome sequence of European mink and European polecat (GenBank accession code: KT693383) showed a discrepancy of 158 single-nucleotide differences [60].

Table 3. Level of similarity (max identity parameter) between the complete sequence of the mitogenome of European mink and selected species of the family Mustelidae (developed using the BLAST program [59]).

\begin{tabular}{lclc}
\hline \multicolumn{1}{c}{ Taxon } & Similarity [\%] & \multicolumn{1}{c}{ Taxon } & Similarity [\%] \\
\hline Mustela putorius & 99 & Enhydra lutris & 87 \\
Mustela putorius furo & 99 & Lutra lutra & 87 \\
Mustela evermannii & 99 & Lutra sumatrana & 86 \\
Mustela nigripes & 98 & Martes melampus & 86 \\
Mustela sibirica & 97 & Martes Americana & 86 \\
Mustela itatsi & 95 & Martes martes & 86 \\
Mustela altaica & 92 & Martes zibellina & 86 \\
Mustela nivalis & 92 & Martes flavigula & 86 \\
Mustela ermine & 92 & Martes foina & 86 \\
Mustela kathiah & 89 & Martes pennant & 86 \\
Mustela frenata & 89 & Gulo gulo & 86 \\
Neovison vison & 88 & Melogale moschata & 86 \\
\hline
\end{tabular}

\section{Identification by Genetic Methods}

Identification of European mink from environmental and noninvasively obtained samples (e.g., hair follicles, feces, and environmental DNA) is important for species in situ conservation efforts [27,46,61-63]. Its distinction from sympatric (or parapatric) N. vison and M. putorius, occurring in the same areas, enables the effective control of the population of the former abovementioned invasive alien species that are dangerous for European mink, and allows the assessment of the possible occurrence and scale of hybridization with the latter species [27,46,47,64-67].

An example is the genetic test for the distinction of European mink, European polecat, and American mink, developed by Gómez-Moliner et al. [27]. The proposed protocol is based on the nested-PCR of the fragment of the mitochondrial control region (D-loop) sequence, followed by digestion of the resulting amplicons ( $240 \mathrm{bp}$ in case of all three species) with a mixture of restriction enzymes RsaI and MspI [27]. The obtained restriction patterns enable the differentiation of both species, discriminating two haplotypes characteristic of $M$. lutreola, two other haplotypes characteristic of M. putorius, and one haplotype characteristic of $N$. vison [27]. The advantage of this method is that it was designed for the use of small amounts of degraded DNA obtained from fecal samples [27].

Another noninvasive method for the identification of European mink, also differentiating it from European polecat and American mink, was developed by López-Giráldez et al. [46]. This method is based on an amplification of the species-specific nuclear microsatellite sequence Mel08, according to the procedure described by Domingo-Roura [68]. At the stage of evaluation of the length of the amplification products, M. lutreola and M. putorius (221 bp product for both species) can be distinguished from $N$. vison (436 bp), whereas the use of digestion with restriction enzyme AciI can distinguish European mink (no digestion occurs) from European polecat (digestion products of 7, 78, and $136 \mathrm{bp}$ ) [46]. The advantage of this method is its simplicity and low cost, and its applicatory 
value is highlighted by the possibility of identifying species that often coexist and belong to the same ecological guild in Europe (semiaquatic carnivorans), despite a totally different approach (control and eradication of the invasive alien population of $N$. vison vs. urgent conservation efforts toward M. lutreola) [27,46]. Collecting the genetic material for the abovementioned tests can be noninvasive by using hair traps for sampling hair with hair follicles [46].

Oliveira et al. [61] developed a molecular test with high discriminatory power based on the polymorphisms detected in a nuclear interphotoreceptor retinoid-binding protein (irbp; $221 \mathrm{bp}$ fragment of exon 1), arguing that identification methods based on mtDNA are subject to risks from nuclear insert copies, high intraspecific diversity, and heteroplasmy. The distinction between European mink, European polecat, and American mink is based on the differentiation of species-specific single-strand conformation polymorphism (SSCP) electrophoretic patterns [61]. The PCR-SSCP method was optimized for scat and hair samples [61]. Comparing species-distinguishing methods using nuclear DNA and mtDNA, the use of only the latter is highly limiting in cases of natural hybridization, which occurs between M. lutreola and M. putorius [49,69].

Kiseleva and Sorokin [70] performed detection of European mink in Chelyabinsk oblast and the Republic of Bashkortostan (Russia) using noninvasive DNA sampling from feces. Individuals of $M$. lutreola were detected by the DNA barcoding method following the protocol developed by Fernandes et al. [71], which is based on two sets of species-specific primers targeting the cytochrome $b$ gene (cytb) sequence (Mlutreola F1/5'-AGCTCATCAACAACTCAC-3' and Mlutreola R1/5'-CCATAGTTGACGTCTCGA-3', amplicon length of $193 \mathrm{bp}$; and Mlutreola F1/5'-AGCTCATCAACAACTCAC-3' and Mlutreola R1b/5'-CCATAATATAAACCCCGC-3' , amplicon length of $280 \mathrm{bp}$ ).

\section{Population Genetics and Phylogeography}

Studies on the population genetics of M. lutreola focused on defining genetic diversity between preserved populations of the species. Analyses of the intraspecies genetic structure of European mink showed its relatively high genetic diversity, especially in comparison with other Mustelidae taxa [72-79]. However, this diversity is not homogeneous, and various populations show significantly different levels of genetic diversity [30].

The studies of Michaux et al. [7] on the interpopulation analysis of genetic diversity of European mink were based on the complete sequence of the mitochondrial D-loop and $450 \mathrm{bp}$ fragment (5'-region) of the cytb gene in 43 individuals: 14 from Russia and Belarus, 2 from Romania, and 27 from France and Spain, with 11, 2, and 1 haplotypes identified for these populations, respectively [7]. The nucleotide diversity $(\pi)$ and haplotype diversity $(h)$ [80] were highest in Northeastern Europe $(0.0197 \pm 0.0025$ and $0.978 \pm 0.035$, respectively), lower in the Romanian population $(0.0039 \pm 0.0019$ and 1 , respectively), and the lowest in Southwestern Europe (0 for both indicators) [7].

In a study conducted in 2005, 15 haplotypes for the complete D-loop were identified in the Russian-Belarussian population (18 individuals examined), four in the Romanian population (34 individuals examined), and only one in the French-Spanish population (124 individuals examined) [8]. The nucleotide diversity and haplotype diversity were $0.012 \pm 0.0014$ and $0.939 \pm 0.058$ for the Russian-Belarussian population, $0.0012 \pm 0.0003$ and $0.469 \pm 0.088$ for the Romanian population, and 0 and 0 for the French-Spanish population, respectively [8]. In the same study, 155 European mink (112 representing the population from Western Europe, 25 from Southeastern Europe, and 18 from Northeastern Europe) were genotyped using five microsatellites (Table 4). Gene diversity $\left(H_{E}\right)$ and allelic richness $\left(R_{S}\right)$ were calculated as 0.539 and 3.76 for Northeastern Europe, 0.458 and 2.89 for Southeastern Europe, and 0.379 and 2.12 for Western Europe, respectively [8]. Microsatellite data revealed that isolation by distance occurs in the Western population, resulting in inbreeding [8]. Multilocus $F_{I S}$ (inbreeding coefficient) values reached 0.084 in the French-Spanish population, 0.085 in the Romanian population, and 0.182 in the Russian-Belarusian population [8]. The calculated value of the mean kinship coefficient between nearby individuals $\left(F_{i j}\right)$ in the population from West Europe was 
0.08 (for distances of $<10 \mathrm{~km}$ ), suggesting mating occurred locally [8]. The obtained results agreed with the outcome of mtDNA analysis, suggesting that the Southeastern and possibly the Western populations underwent a recent bottleneck [8].

An important outcome of the research of Michaux and colleagues [7,8], as well as further studies of Cabria et al. [30] is the identification of three genetically distinguishable extant populations, i.e., the Northeastern European (inhabiting the Volga and the Dvina basin in Russia), the Western European (inhabiting the Southwestern part of France, as well as Northern and Western parts of Spain), and the Southeastern European (inhabiting the Danube Delta in Romania) populations. This conclusion is supported by the results of intraspecific genetic structure analysis, indicating statistically significant pairwise values of fixation indexes [81,82]: $F_{S T}(0.10$ between SE and NE Europe, 0.29 between W and SE Europe, and 0.26 between W and NE Europe), $G_{S T}$ ( 0.89 between SE and W Europe, 0.54 between W and NE Europe, and 0.42 between NE and SE Europe), and $\Phi_{S T}(0.91$ between SE and W Europe, 0.71 between $W$ and NE Europe, and 0.26 between NE and SE Europe) [8]. Michaux et al. [8] claimed that the abovementioned values of fixation indexes prove a weak phylogeographical structure for European mink.

Relatively high genetic diversity in the Eastern European population was confirmed by Korablev et al. [83], who examined 11 individuals from the Tver region (Russia). Genotyping based on the $526 \mathrm{bp}$ fragment of the mtDNA D-loop revealed the presence of eight haplotypes, with the calculated values of the indices of nucleotide and haplotype diversity as follows: $\pi=0.0092 \pm 0.0055$ and $h=0.95 \pm 0.054$ [83]. Analysis involving additional sequences, described by Michaux et al. [7] (Table 4), showed notably increased values of these indices, i.e., $\pi=0.0134 \pm 0.0074$ and $h=0.98 \pm 0.027$ [83]. European mink is characterized by a higher level of intrapopulation genetic variation than the European polecat from the same region $(\pi=0.0026 \pm 0.0019$ and $h=0.74 \pm 0.052)$ [84]. The difference in the values of genetic diversity parameters in both species can be explained by species-specific ecological and biological features, as well as by differences in population history in a given area [83]. An important conclusion from these studies is that local extinction in the Tver region is not a consequence of genetic decline manifested by a reduction in genetic diversity below the critical level or inbred depression [83].

Table 4. Genetic markers used in research on M. lutreola population genetics.

\begin{tabular}{ll}
\hline \multicolumn{1}{c}{ Study } & \multicolumn{1}{c}{ Genetic Markers } \\
\hline Michaux et al. [8] & Mvi072, Mvi075, Mer009, Mer022, Mer41 \\
\hline Korablev et al. [83] & GenBank accession codes: AJ548805-AJ548807, AJ548812, AJ548814, AJ548817 \\
\hline Cabria et al. [30] & Mlut04, Mlut20, Mlut25, Mlut32, Mlut35, Mer09, Mer22, Mer41, Mvi022, Mvi072, Mvi075 \\
\hline & fragments of the genes for AAT-1 and AAT-2-E.C. 2.6.1.1, ACO-1 and ACO-2-E.C. \\
& 4.2.1.3, ADA E.C. 3.5.4.4, AK E.C. 2.7.4.3, CK-1 and CK-2-E.C. 2.7.3.2, DDH-1 and \\
& DDH-2-E.C. 1.8.1.4, EST-1 and EST-2-E.C. 3.1.1.1, FUMH-E.C. 4.2.1.2, \\
& Gly2DH-E.C. 1.1.1.29, G6PDH-E.C. 1.1.1.49, GPI-E.C. 5.3.1.9, HK-1, HK-2 and \\
& HK-3-E.C. 2.7.1.1, IDH-1 and IDH-2-E.C. 1.1.1.42, LDH-1 and LDH-2-E.C. 1.1.1.27, \\
Lodé [14] & MDH-1 and MDH-2-E.C. 1.1.1.37, ME-1 and ME-2-E.C. 1.1.1.40, MPI-E.C. 5.3.1.8, \\
& PEP-1 and PEP-2-E.C. 3.4.11.1, PGDH-E.C. 1.1.1.44, PGM-2-E.C. 2.7.5.1, PNP-E.C. \\
& 2.4.2.1, SDH-E.C. 1.1.1.14, SOD-E.C. 1.15.1.1, TPI-E.C. 5.3.1.1, and two \\
\hline Peltier and Lodé [45] & Mvi002, Mvi020, Mvi072, Mvi389, Mvi1843, Mvi054, Mvi111, PutFK1 \\
\hline Lodé et al. [49]- & Mvi002, Mvi020, Mvi027, Mvi054, Mvi072, Mvi075, Mvi099, Mvi111, Mvi389, \\
population genetics & Mvi1843, PutFK1 \\
\hline Lodé et al. [49]—M. lutreola $\times$ & allozymic loci: Ada, Est-2, Mdh-1, Me-1, Pep-2, microsatellite loci: Mvi002, Mvi020, \\
M. putorius hybrids & Mvi075, Mvi1843 \\
\hline Cabria et al. [47] & Mlut04, Mlut20, Mlut25, Mlut27, Mlut32, Mlut35, Mvi22, Mvi72, Mvi75, Mvi99, Mer09, \\
\hline
\end{tabular}

Cabria et al. [30] focused on 11 microsatellite loci (Table 4) and the $614 \mathrm{bp}$ mtDNA fragment including the $3^{\prime}$-end of the $c y t b$ gene and the control region of 344 individuals. The established parameter values for evaluating the genetic diversity for microsatellite loci are summarized in Table 5; 
the sequence variability of mtDNA (analyzed in 157 specimens) ranged from high for the Northeastern population ( $\pi=0.004 \pm 0.003, h=0.862 \pm 0.016,13$ haplotypes, $92.3 \%$ of private haplotypes) and moderate for the Southeastern population $(\pi=0.0019 \pm 0.0015, h=0.352 \pm 0.0103$, four haplotypes, $75 \%$ of private haplotypes), to the lowest for the Western population (only a single haplotype detected). The nucleotide and haplotype diversities calculated for the whole examined group were $0.005 \pm 0.003$ and $0.857 \pm 0.014$, respectively [30]. Analysis of the genetic structure of the remaining populations of $M$. lutreola revealed significant geographic structuring (pairwise $\Phi_{S T}$ values calculated based on mtDNA variability ranged from 0.586 to 0.879 , whereas the mean $F_{S T}$ for microsatellite data was 0.224 ). The presented results indicated higher overall genetic polymorphism and structure in the Northeastern population, slightly lower values in the Romanian population, and significantly lower values in the Western population [30].

Table 5. Indicators of genetic variety of the Northeastern (NE), Southeastern (SE), and Western (W) populations of European mink, based on 11 microsatellite loci [30].

\begin{tabular}{lcccccccc}
\hline Population & $\boldsymbol{N}$ & $\boldsymbol{N}_{\boldsymbol{A}}$ & $\boldsymbol{P}_{\boldsymbol{A}}$ & $\boldsymbol{\%}_{\boldsymbol{P}_{\boldsymbol{A}}}$ & $\boldsymbol{A}$ & $\boldsymbol{H}_{\boldsymbol{O}}$ & $\boldsymbol{H}_{\boldsymbol{E}}$ & $\boldsymbol{F}_{\boldsymbol{I S}}$ \\
\hline NE & 107 & 59 & 20 & 33.90 & 5.364 & $0.559 \pm 0.153$ & $0.613 \pm 0.164$ & 0.089 \\
SE & 44 & 35 & 2 & 5.71 & 3.182 & $0.464 \pm 0.170$ & $0.496 \pm 0.139$ & 0.065 \\
W & 162 & 32 & 3 & 9.38 & 2.909 & $0.336 \pm 0.161$ & $0.439 \pm 0.201$ & 0.236 \\
TOTAL & 313 & 64 & - & - & 5.818 & $0.430 \pm 0.113$ & $0.578 \pm 0.148$ & 0.255 \\
\hline
\end{tabular}

$N$, number of examined individuals; $N_{A}$, number of alleles identified; $P_{A}$, number of private alleles; \% $P_{A}$ percentage of private alleles in total number of alleles; $A$, allelic diversity; $H_{O}$, observed heterozygosity; $H_{E}$, expected heterozygosity; $F_{I S}$, inbreeding coefficient.

Studies conducted by Davison et al. [28] and Cabria [29] led to similar conclusions regarding the genetic diversity of the three abovementioned populations of European mink. Davison et al. [28] identified four haplotypes of the $337 \mathrm{bp}$ fragment of the mitochondrial cytochrome $b$ gene in the Eastern European population (30 individuals examined) and two in the Spanish population ( 7 individuals examined). The same study revealed the existence of four different haplotypes in both the Eastern European and Spanish populations of M. putorius.

The cause of high genetic homogeneity of populations living in France and Spain is attributed to the bottleneck and founder effects that might have occurred (one or several times) in the relatively recent past, as well as to the limited gene flow, thereby altering reproductive exchanges $[8,14,30]$. According to these findings, the population of France and Spain originated in Northern France at the beginning of the 19th century from a few specimens separated from other European populations [8]. The founders probably came from an ancestral Eastern population (encompassing both the Northeastern and the Southeastern genetic pools) during a period of population admixture [30], whereas recolonization after the last glaciation probably occurred from a single refugium supposedly located in Eastern Europe or Asia $[7,8,28]$. The results of large-scale genetic research by Cabria et al. [30] supported the scenario of stable populations of European mink during Late Pleistocene climate oscillations and expansion along rivers following the last glaciation period, further local extinctions in central Europe, and recent bottleneck events throughout Europe.

These conclusions were also supported by results of genetic polymorphism analysis of 38 genes' loci (Table 4) conducted on 12 animals from Western France [14]. Of the used loci, only four (Est-2, $M d h-1, M e-1$, and $P n p)$ were found to be polymorphic $\left(H_{O}=0.09,0.08,0.10\right.$, and 0.50 , respectively; $H_{E}=0.37,0.08,0.48$, and 0.52 , respectively), with observed heterozygosity averaging 0.02 , an expected heterozygosity of 0.038 , and an $F_{I S}$ of 0.48 [14]. In European mink, only $10.5 \%$ of loci were shown to be polymorphic; in the European polecat population from Western France $(N=49)$, the polymorphism reached $25.8 \%$ and the observed heterozygosity levels averaged 0.057 [85].

Eight microsatellite loci (Table 4) in 12 individuals of M. lutreola from the Poitou-Charentes region (Western France), conducted by Peltier and Lodé [45] were genotyped to survey the genetic diversity and population history and confirm the heterozygote deficit resulting from inbreeding $\left(F_{I S}=0.1907\right)$. 
The authors suggested that a significant heterozygote deficit in the Southwestern population of European mink was associated with depletion of genetic diversity, which is characteristic of species near extinction.

The level of genetic polymorphism in the French population (Southwestern France) was also studied by Lodé et al. [49]. Genetic variation was measured from 38 gene loci described by Lodé [14] and 11 microsatellite markers (Table 4) in 51 individuals. Only four (10.5\%) allozyme loci (Est-2, Mdh-1, Me-1, and Pnp) and four (36.4\%) microsatellite loci (Mvi027, Mvi072, Mvi1843, and PutFK1) were found to be polymorphic. The effective number of microsatellite alleles per locus was estimated at 1.45 and mean observed heterozygosity was 0.095 [49]. In this case, the level of heterozygosity in European mink was significantly lower than that observed in European polecat $\left(H_{O}=0.246, N=114\right)$, according to parallel analysis [45].

High phenotypic diversity, expressed in the postulated distinction of six [86] to seven [87] subspecies of European mink (Mustela lutreola lutreola L., 1761, M. l. biedermanni Matschie, 1912, M. l. binominata Ellerman and Morrison-Scott, 1951, M. l. cylipena Matschie, 1912, M. l. novikovi Ellerman and Morrison-Scott, 1951, M. l. transsylvanica Éhik, 1932, and M. l. turovi Kuznetsov and Novikov, 1939), was not confirmed by intraspecies genetic diversity studies. In the view postulated by Cabria et al. [30], populations of European mink throughout most of the species evolutionary history formed a panmictic continuum. The reason for the observed genetic differentiation between the Russian and Spanish-French populations was suggested to be a recent, human-induced, distance isolation [30]. Currently, recorded morphological differences between populations (e.g., more frequent occurrence of a white patch on the chest for individuals from Eastern Europe) are thought to be an effect of genetic drift $[12,30]$.

Notably, knowledge about the origin of certain populations derived from genetic data affects their management and conservation. An example illustrating this is the lively debate on the controversial natural (colonization) or human-induced (introduction) origin (as suggested by Michaux et al. $[7,8]$ and Cabria et al. [30]) of the French-Spanish European mink population [3,11,88-93].

\section{Phylogenetics}

The results of pioneering molecular research on European mink phylogeny based on mitochondrial sequence (cytb, $12 S$ rRNA and the 5'-fragment of the D-loop) were reported by Davison et al. [94]. These results suggested a close evolutionary relationship between M. lutreola and polecats (M. putorius and M. eversmanii, as well as $M$. nigripes, though less expressed), and its more distant relationships with $M$. sibirica and M. itatsi [94]. Further analysis based on the cytb gene and the D-loop sequence confirmed these results [28]. High similarity between the analyzed mtDNA sequences of European mink and polecats (M. putorius and M. eversmanii) may be evidence of relatively recent speciation or gene flow through hybridization (reticulate evolution) occurring between these species $[28,94]$.

The phylogenetic analysis based on the nucleotide sequence of the nuclear irbp gene and the mitochondrial cytb gene, performed by Sato et al. [24], proved that M. lutreola belongs in the clade including European polecat, steppe polecat, Siberian weasel, and Japanese weasel (Figure 1A,B). The close evolutionary relationship between European mink, European polecat, and steppe polecat was also evidenced by the results of a phylogenetic analysis based on the sequences of mitochondrial genes $12 S$ rRNA $[31,42,95]$ and $c y t b[22,25,31]$, and the gene encoding the NADH dehydrogenase subunit 2 [31], as well as the nuclear genes (the gene for thyroxine-binding globulin [31], irbp [31,95], the transthyretin-encoding gene [31], and the Mel08 complex repetitive flanking regions [25]). Sequences of $M$. lutreola nuclear genes (recombination activating gene 1, interphotoreceptor retinoid binding protein gene, apolipoprotein B gene, and transthyretin gene) were also used in a multispecies analysis of diversification timing of taxonomic groups within the Mustelidae family [96]. 
A

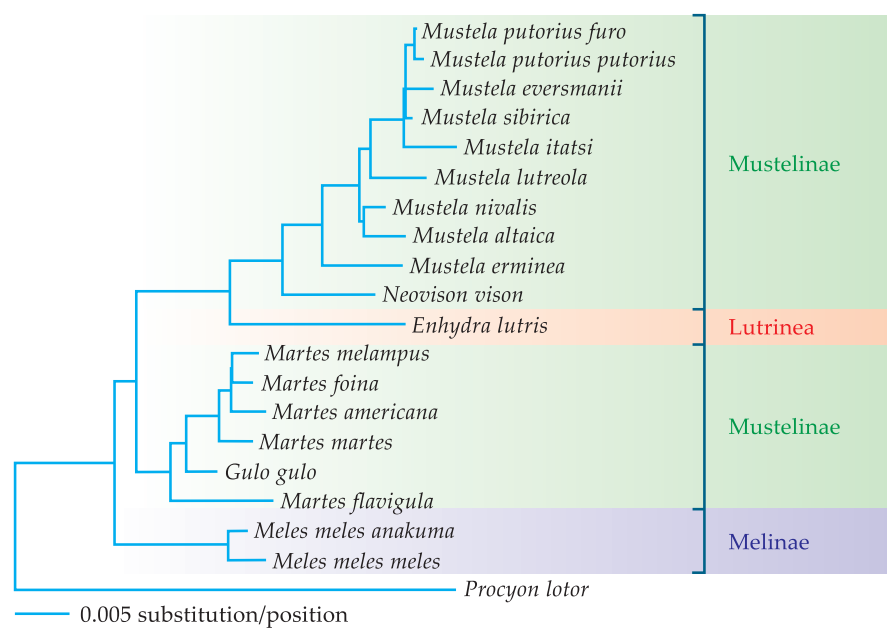

B

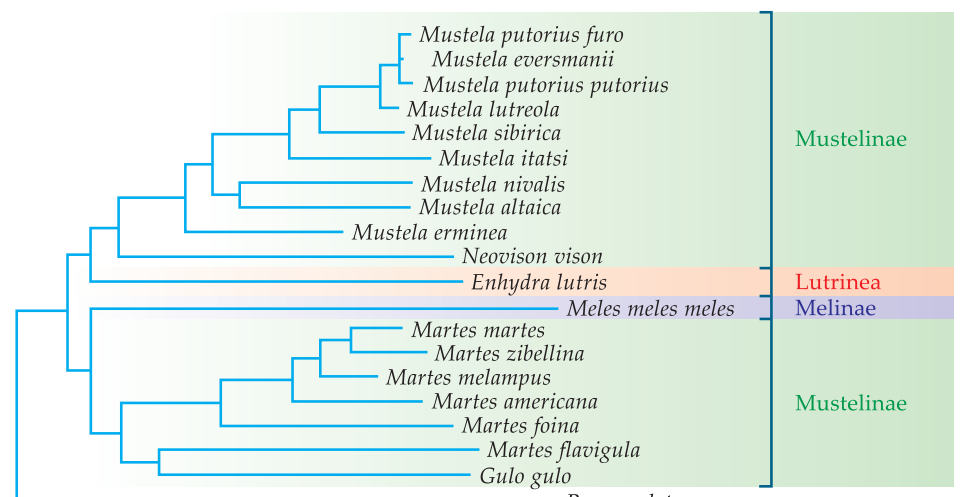

0.01 substitution/position

C

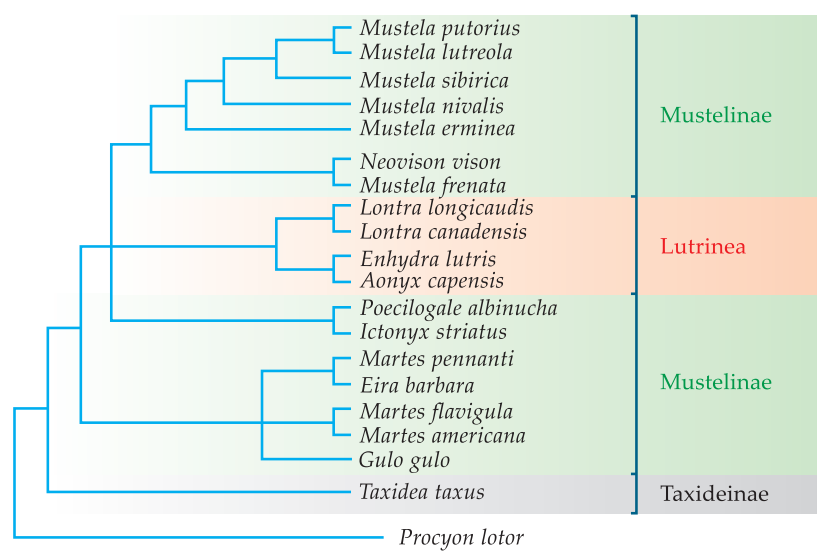

Figure 1. Dendrograms constructed for the Mustelidae family based on (A) nucleotide sequences (partial) of the irbp gene using the neighbor-joining method (the horizontal length of each branch is proportional to the number of nucleotide substitutions per site) [24], (B) complete nucleotide sequences of the cytb gene using the neighbor-joining method (the horizontal length of each branch is proportional to the number of nucleotide substitutions per site) [24], and (C) the sequences of $12 S$ rRNA, cytb, ND2, $t b g$, irbp, and $t \operatorname{tr}$ (first intron) genes using the maximum parsimony method with bootstrap support (1000 replicates) [31].

The multigene phylogenetic studies conducted by Flynn et al. [31] based on the fragments of sequence of three mitochondrial (12S RNA, cytb, and ND2) and three nuclear ( $t b g$, irbp, and ttr) genes were particularly interesting. The results of these studies indicated that the European polecat is 
phylogenetically the closest species to European mink, whereas other closely related species include the Siberian weasel, the least weasel, and the stoat (Figure 1C).

According to phylogenetic analyses of Davison et al. [28] M. putorius, M. eversmannii, and M. lutreola should, despite the close evolutionary relatedness, be considered separate Evolutionary Significant Units (ESUs).

The phylogenetic distance between the European mink and the American mink is much greater than between M. lutreola and M. putorius, M. eversmanii, M. nigripes, M. sibirica, or $M$. itatsi $[24,26,31,42,57,94,95,97,98]$. American mink was separated from Eurasian representatives of the Mustela genus, including M. lutreola, and instead classified into the separate genus Neovison by Baryshnikov and Abramov in $1997[99,100]$.

\section{Molecular Ecology}

Research concerning European mink in the field of molecular ecology, understood as the application of molecular genetic methods to address ecological questions [101], is mainly related to the ecology of pathogens (molecular epizootiology). Viral metagenomic analysis of European mink feces (collected in the Northern part of Spain), based on a random PCR in combination with next-generation sequencing, revealed the presence of genetic material of viruses from the following genera: Amdovirus, Dependovirus, Parvovirus, Astrovirus, and Picobirnavirus [34].

Recently, the nucleotide sequence of the angiotensin I converting enzyme 2 gene in M. lutreola was investigated to examine the potential of its protein product to be used as a receptor by the SARS-CoV-2 virus, and thus to verify if European mink could potentially be an intermediate host species for this pathogen [36]. The obtained results indicated very low predicted susceptibility of M. lutreola to SARS-CoV-2 [36].

Mañas et al. [102] detected the sequence of the VP2 gene of the Aleutian mink disease virus (AMDV) using a PCR method in European mink from Spain. Leimann et al. [35] tested four individuals of M. lutreola from Hiiumaa Island (Estonia) for the presence of the AMDV DNA by PCR amplification of the NS1 and VP2 gene fragments. AMDV DNA was not detected in the examined animals [35].

An example of a bacterial pathogen identified in European mink using a PCR-Restriction Fragment Length Polymorphism (RFLP) method is Borrelia burgdorferi, which was the first report in this regard concerning animals originating in Romania [33]. Moinet [103] tested the renal samples of M. lutreola (Southwestern France) for the presence of pathogenic Leptospira interrogans DNA by PCR amplification. Of the 34 examined individuals, 8 were found to be infected with this pathogen, however, the role of European mink as a reservoir of L. interrogans was not confirmed [103].

In 2019, a pilot study on European mink detection and population monitoring using the environmental DNA (eDNA) metabarcoding method was performed in Northeastern Spain (La Roja and Basque Country) $[62,63]$. Due to its semiaquatic lifestyle, European mink DNA has a high detection potential from environmental (freshwater) samples, as is the case with other species living in aquatic environments [104,105].

\section{Conservation Genetics}

Although the number of studies on the genetics of European mink is relatively low, the important application aspect of almost every study in this field should be emphasized. Such studies directly contribute to obtaining valuable and practical knowledge about planning effective protective measures, both ex situ (conservation captive breeding) and in situ (reintroduction programs supplying the disappearing populations with individuals from the outside), conducted both ad hoc and as long-term strategies $[7,66,89,106,107]$. Conservation genetics can provide ready-to-use, measurable, and highly informative tools for defining conservation goals and means, which are crucial for the conservation of European mink $[7,8,30,89,96,108]$. Pioneering research, opening the chapter of European mink conservation genetics, was undertaken by Lodé [14]. 
The key issues for M. lutreola conservation to be addressed by conservation genetics are: (1) Determining the optimal species conservation scenario for management of the existing populations, including translocations and reintroductions (population restoration programs, repopulation); (2) captive breeding genetics; and (3) identification and assessment of possible threats to interspecies genetic nature, i.e., hybridization and introgression $[7,8,66,108]$.

Since the publication of the first study results showing significant differences in genetic diversity between the Northeastern, Western, and Southeastern populations of European mink, the ESU concept [109] and definition of a management unit [110,111], which are useful for conservation purposes, represented hotly debated issues [89]. Originally, it was postulated to follow the precautionary principle, thus separately managing animals from the three geographically distinct populations $[7,28]$. The rationale for this approach was the risk of outbreeding depression [110], which is caused by individuals introduced from the outside and resulting in reduction in local adaptation [7]. Currently, the widely accepted interpretation of further genetic research involving larger samples and combined mitochondrial and nuclear markers is that European mink can be regarded as a single ESU and none of the three remaining populations demonstrate independent evolutionary development or a specific phylogeographic structure $[1,8,30,112]$. A critical assessment of this statement led to the assumption that, although the current large interpopulation genetic variation as a function of geographical distance does not automatically imply the phylogeographic structuring of the species (considering the time dimension apart from the geographical dimension), the currently observed genetic variation can be directly calculated (and may be only affected by measurement error), whereas the phylogeographic inference is indirect and secondary (and may be additionally affected by interpretation error).

The consequence of such reasoning is the acceptance of supplying the Western European ex situ stock with individuals from the Eastern European ex situ stock, exhibiting "better" values of the genetic diversity indicators [12]. Additionally, the translocation and (re)introduction of individuals from the captive Eastern population was suggested if inbreeding depression in French and Spanish wild populations were to be confirmed [2]. Cabria et al. [47] suggested the implementation of European mink conservation strategies that improve genetic connectivity by promoting gene flow among the scattered remaining populations. Restoration of reproductive exchanges was recommended by Lodé [14]. The European mink's situation is basically similar to those of many other endangered mammal species in Western Europe, for which recovery projects mainly rely upon translocation of conspecifics from viable populations in Eastern Europe [113]. In planning, implementing, and evaluating the genetic management of $M$. lutreola, including reintroductions and translocations, experience in the conservation of closely related endangered species, e.g., the black-footed ferret, can be used [114-117].

The case of inbreeding depression is not simple and obvious-even if a loss of genetic variability is regarded as one of the major threats to European mink conservation [45], the low level of genetic diversity recorded in the French and Spanish populations being natural and not impairing species plasticity in habitat use and colonizing capacity cannot be ruled out (the so-called "mink paradox") [14,118]. The genetic consequences of range expansion, such as the structuring of newly colonized areas into distinct sectors of low genetic diversity [119] as well as the phenomenon of heterozygosity excess following bottleneck events lasting for several generations [120], seemed to be overlooked by authors who interpreted the low genetic variation in populations from France and Spain. However, Carbonell [89], after Dlugosch and Parker [121], concluded that losses of quantitative variation in expanding populations may be minimal compared with losses of molecular variation.

Considering the historical range extent of European mink, an interesting colonization scenario hypothesis, according to which the French population of M. lutreola originates from the Black Sea area, was formulated by Lodé [118]. According to this hypothesis, the expansion occurred along the Danube, passing through the north of the Alpine arc and following the Loire River toward Western France [118].

The potential risk of outbreeding depression (which is connected with translocations between populations) as noted previously, needs to be further investigated and assessed [8,28,30,122]. Increasing the number of samples and broadening their geographical representation, as well as increasing the 
number of analyzed sequences (including genomic analysis), are not substitutes for a comparative analysis of intraspecies genetic diversity in the historical dimension. Such research requires a comparative analysis of samples from contemporary and historical populations (aDNA obtained from fossils and museum specimens, natural history collections), including those from areas where the species is no longer present. Inferences about the causes and effects of the currently observed genetic variation in European mink without historical comparative analysis would be speculation. The problem regarding the lack of comparative aDNA material was reported by Cabria et al. [30]. Knowledge of the original resources of genetic diversity would allow proper assessment of the present state of the species' gene pool, providing baseline levels of diversity, inbreeding, and genetic load [117,123]. This knowledge can further be used to predict how organisms might respond to human-induced global change in the future [124].

Historical material, although on a limited scale covering the period 1983-2006, was included in the analysis of genetic variation conducted by Korablev et al. [83] for the European mink population in the Central Forest Reserve (Tver oblast) in Russia. The authors concluded, based on the results of genetic and morphometric (dynamics of odontological and craniological characteristics) analyses, that the catastrophically rapid extinction of M. lutreola in the study area, preceded by a period of population insularization, led to a gradual reduction in its phenetic polymorphism, albeit without major loss of genetic diversity [83].

For management units, since the results of the conducted research did not allow for their definition, the concept of a distinct population segment (DPS) was proposed to apply to European mink $[7,8,125]$. According to Michaux et at. [8] and Cabria et al. [30], the remaining three main populations of European mink cannot be considered DPSs, as genetic variation was not found to be geographically structured among the three European populations of M. lutreola. Nevertheless, the results indicated highly significant differences in parameters describing the genetic diversity between all three populations of European mink [7,8,28-30,45,49,85]. A review of research showed that promotion of the pragmatic interpopulation translocations should not be justified by misinterpretation of the results of genetic analyses, but rather by the need to choose the lesser evil in the critical situation of a species experiencing extinction before our eyes. A lesser evil in this context means assuming the risk of outbreeding, losing the geographical originality of the population gene pool, and the potential loss of local adaptations.

Important aspects for in situ conservation of wild populations are the demographic indicators that describe the conditions needed to retain genetic diversity in the population and determine the potential survival of endangered species, i.e., effective population size $\left(N_{e}\right)$, which determines heterozygosity decreases due to genetic drift at a rate of $1 / 2 N_{e}$ per generation, and genetic neighborhood area $\left(N_{a}\right)$, which represents the area within which adults can randomly mate [15,126-128]. Both indicators were estimated for the population of European mink from Southwestern France (Charente-Maritime) by Lodé and Peltier [15] to assess how its decline affected the ability to retain genetic diversity in the population. The calculated value of $N_{a}$ was a diameter of $31.7 \mathrm{~km}$, allowing for population size within the neighborhood area to range from 16.1 to 22.8 individuals [15]. The $N_{e} / N$ ratio, where $N$ is the adult population size, ranged from 0.089 to 0.197 for the studied population [15], which is close to the average for wildlife populations, as reported by Frankham [129]. The estimated value of the genetic neighborhood area provides a guide for the designation of protected areas dedicated to European mink conservation [15].

Although the abovementioned achievements of population genetics, phylogenetics, phylogeography, studies on genetic markers, identification by genetic methods, and molecular ecology of European mink focused on wild populations and their conservation in situ, captive breeding genetics addresses the issues of maintaining and developing captive stocks to preserve the species' genetic pool. Captive (or conservation) breeding genetics can be defined as a subfield of conservation genetics that aims to provide genetic theory and techniques for conservation breeding of captive wildlife stocks before the reintroduction (repopulation) phase can be achieved. The key issues covered by captive breeding genetics for M. lutreola include the selection of individuals intended for mating 
(reproduction), preventing inbreeding and genetic erosion in ex situ stocks, and studying the genetic basis of traits that are important for reproduction in captivity [130].

The first conservation breeding program for European mink was launched in the Tallinn zoo (Estonia) in 1984; the European Endangered Species Program (EEP) for the species was launched by the European Association of Zoos and Aquaria (EAZA) in 1992 [4,66]. The captive stock comes from 22 founders, mostly originating from Northeastern and central Russia, and currently includes 220 individuals [12]. The total European mink ex situ EEP population is 267 [12]. Animals are kept in 26 breeding facilities in Czechia, Estonia, Finland, France, Germany, Latvia, the Netherlands, Poland, and Slovakia [66]. A regional captive breeding program was also initiated in Spain in 2004, with 10 founders captured in the country [66]. Currently, about 47 breeding individuals are held in nine breeding centers in Spain [12]. Since 2010, breeding of European mink was carried out in the European Mink Breeding Centre of the Ilmen Nature Reserve (Chelyabinsk oblast, Russia) [131]. The 30 founders of this captive stock were from the Institute of Systematics and Ecology of Animals of the Siberian Branch of the Russian Academy of Sciences in Novosibirsk (Russia), where European mink was first bred in captivity in the 1970s and continues to be bred here [132]. There are also plans to establish an ex situ breeding center in Romania [12].

The conservation goal of the captive breeding programs for M. lutreola is to preserve the genetic diversity of the species in captivity, as well as supply individuals for reintroduction [133]. They also play an important role in research applications in the field of conservation genetics [12,134]. Captive-born animals from the EEP program are used for reintroduction purposes in Estonia and Germany, whereas reintroductions in Spain use individuals born under the Spanish captive breeding program [66,135]. Specifically, the EEP program for M. lutreola aims to maintain $97.5 \%$ of the original genetic diversity of the founders in an ex situ population for as long as possible [12].

Effective population size for the Eastern ex situ population was calculated as 65.6 individuals [133]. Maran et al. [12] reported the values of the following genetic indicators for the captive population, namely, founder genome equivalents (FGE; the number of wild-caught individuals/founders that would produce the same amount of gene diversity as does the population under study), (retained) genetic diversity ( $G D$; the probability that two alleles from the same locus sampled at random from the population will not be identical by descent), population mean kinship ( $M K$; the proportional loss of gene diversity of the descendant captive-born population relative to the founders and to the mean inbreeding coefficient of progeny produced by random mating), mean inbreeding ( $I$; the probability that the two alleles at a genetic locus are identical by descent from an ancestor common to both parents), and effective population size/census size ratio $\left(N_{e} / N\right)$. The values of the indicators for the Eastern (EEP) and Western (Spanish) European captive populations were: FGE, 7.3 and 1.18; GD, 93.2\% and 57.5\%; $M K, 0.068$ and $0.425 ; I, 0.079$ and 0.364 ; and the $N_{e} / N$ ratios were 0.283 and 0.073 , respectively [12].

Conservation breeding programs are characterized by the selection of the genetically most suitable pairs for reproduction, identified according to their genetic representation among the population to avoid inbreeding [136]. A common problem is that the specifically selected partners for breeding do not mate during the breeding attempts [136]. Kneidinger et al. [136] reported that, on average, just over $30 \%$ of the planned litters were sired by the genetically prioritized males. The influence of selection on the behavioral traits of breeding males on shaping the gene pool in captivity is not yet recognized. Aggressive behavior by the male toward the female excludes the former from mating, but without knowledge of the possible heritability of personality traits, it is not possible to assess the risk of decreasing genetic variation in the reintroduced populations posed by selection for release of individuals with specific personality types [136-138]. Conservation genetics can help to gain further insight into the impact of genetic factors, which, in addition to environmental conditions, cause the low breeding success of M. lutreola individuals in captivity [133].

Conservation breeding of M. lutreola in captivity may be enhanced by implementation of assisted reproductive techniques (ARTs), including semen and embryo cryopreservation, artificial insemination, and embryo transfer [12,134,139-141]. The use of ART, however, requires analysis of their potential 
impact on the genetic parameters of the offspring (e.g., as reviewed by Lin and Tsai [142]), and there are no reports of such studies for European mink in the available literature. Development of protocols for European mink sperm cryopreservation and biobanking of DNA samples and other biomaterials (genome resource banking (GRB)) to facilitate future research and interventions is planned under the EEP program dedicated to this species [12]. Biobanked semen, or even fibroblast cell lines, could be used to revive genetic diversity that was lost over time [143].

The role of captive breeding of European mink is of critical importance for the survival of the species. However, per Ehrlich [144], "the loss of genetically distinct populations within species is, at the moment, at least as important a problem as the loss of entire species". Therefore, efforts to conserve the genetic resources of the preserved wild populations of $M$. lutreola in situ cannot be overestimated. Conservation genetics can provide knowledge that could be applied to reorient conservation strategies to prioritize the survival of threatened distinctive populations [113]. Appropriate guidance can be provided by the lesson learned from the M. nigripes, M. eversmanni, and M. putorius conservation breeding and reintroduction program $[116,117,143,145-149]$. When a species is threatened with extinction, the timing of measures to conserve genetic resources is of particular importance. Due to the decreasing sizes of the preserved populations (resource constraints increasing over time) and the increasing risk of inbreeding depression limiting natural breeding success, GRB and ART programs need to be initiated before genetic health issues arise [143].

It was claimed that genetically managed, long-term breeding programs within zoological gardens can be a source of individuals for reintroduction [150]. However, the question still remains regarding the differences in genetic diversity of wild and captive populations, regardless of their geographical origin, as European mink may be subject to reduced natural selection pressure in captivity [50]. Becker et al. [50] stated that this aspect should be considered whenever founder individuals for breeding and reintroduction are selected. Selective conservation breeding may lead to an increase in inbreeding, resulting in genome-wide loss of variation [151].

Two important issues addressed by conservation genetics include whether the risks of hybridization and introgression exist for European mink and, if so, the size of these risks. The close phylogenetic relationships between European mink and European polecat were proven by the lack of a complete interspecies reproductive barrier between these taxa, expressed by spontaneous hybridization in nature $[28,47,49,152]$. Davison et al. [28] indicated that at least one mtDNA haplotype was shared between both species, suggesting mitochondrial introgression. The hybridization is asymmetric, as M. putorius males mate with M. lutreola females [2]. The number of chromosomes ( $2 n)$ in hybrids can be 39 or 40 [1]. The frequencies of hybridization and genetic introgression in natural conditions are low, estimated at $\leq 3 \%[47,49]$ and $0.9 \%$ [47], respectively. Even if natural hybridization events occur only occasionally, interspecies gene flow can play some role, especially in accelerating local extinction of declining and fragmented populations, e.g., by outbreeding depression $[1,28,47,49,153]$.

Identification of hybrids using genetic methods is important for captive breeding, as using hybrids in the ex situ breeding programs is not advisable [153]. Potential for hybridization and its management should also be considered in reintroduction planning and implementation, as it poses a risk to the genetic integrity of the reintroduced populations [154,155]. Lodé et al. [49] described a method of discrimination between European mink, European polecat, and their hybrid based on differences in five allozymic and four microsatellite diagnostic loci (Table 4). The hybrid showed an intermediate pattern for microsatellite markers [49].

Analyses conducted by Cabria et al. [47] involved 317 European mink, 114 polecats, and 15 putative hybrids from different localities in Europe. Assigning individuals to species (or hybrid group) was based on genotyping with 13 microsatellite nuclear markers (Table 4) and Bayesian analysis of biparental multilocus genotypes employing clustering based on allele and genotype frequencies. Private haplotypes exhibiting high discriminating power accounted for $34.33 \%$ and $27.03 \%$ of all identified haplotypes in European mink and European polecat, respectively, while most alleles shared 
by these species showed differences in the distribution of allele frequency between species [47]. Of 14 detected hybrids, 12 were from French and Spanish populations [47].

Hybridization direction (paternal and maternal origins) was detected by direct nucleotide comparison of a sequenced $614 \mathrm{bp}$ mitochondrial control region and partial sequences of introns 5 and 7 of the DDX3Y gene located on the Y chromosome [47]. The obtained results proved that hybridization is asymmetric, as only pure European mink females mated with pure European polecat males, and backcrossing and genetic introgression only occurred from female first-generation $(F 1)$ hybrids of M. lutreola to M. putorius [47]. An important implication of the described research was that the continuing decline of European mink may be associated with the growing significance of hybridization as one of the most important threats to the survival of the species due to the increasing avoidance of conspecific mates [47]. Additionally, the identified asymmetry in the hybridization process may, given the progressive decline of remaining populations, lead to a progressive assimilation (introgression) of European mink by European polecat [47,49].

The possibility of crossbreeding between European mink and the ferret M. putorius furo $[156,157]$ was also reported. No possibility of crossbreeding between European mink and American mink $[157,158]$ or Siberian weasel [159] was proven. Hybrid embryos for of these species obtained in laboratory conditions exhibited pathological characteristics and were resorbed in a short time [158,159].

The final reflection on the European mink conservation genetics may be a reference to the definition of this subdiscipline of genetics, namely, a reminder that the imperative, apart from preserving the natural intraspecies genetic diversity, is to ensure the continuity of evolutionary and ecological processes responsible for the formation and maintenance of this diversity [32].

\section{Conclusions}

The overall conclusion from the analysis of the history and scope of genetic research on European mink is a gradual increase in the genomic representativeness of the nucleotide sequences used. This trend is in line with the widespread transition from genetics to genomics, which is also (and perhaps especially) observed in conservation genetics [160-162]. Important in the case of M. lutreola, advanced genomics (whole-genome and reduced-representation approaches) can help to describe and explain adaptive genetic variations, resolving phylogenetic and phylogeographic questions, identifying adaptive alleles, as well as identifying and quantifying inbreeding, hybridization and introgression in a more accurate way than genetics [163-167]. Whole-genome sequencing also provides valuable knowledge about the origin and evolutionary history of endangered species and defines units for conservation, thus helping to improve conservation strategies $[165,166]$. For a nonmodel endangered species, such as European mink, obtaining a reference genome is essential $[168,169]$.

Genomic methods considerably improved conservation efforts toward some mammalian endangered species. The whole-genome approach was previously applied to the conservation of African wild dog Lycaon pictus to detect inbreeding and population-specific selection [170]. Genomics provides tools for population evaluation monitoring and management of small populations in the wild and in captivity, species delineation, and to enhance wildlife health management and identify risk factors for genetic disorders of endangered primates [171-173]. Conservation genomics helped to identify the conservation implications of admixture in the Eastern wolf Canis lupus lycaon [165]. Wright et al. [174] identified several candidate genes that may be associated with variation in the breeding success of the Tasmanian devil Sarcophilus harrisii. From the M. lutreola population genetics perspective, the same research demonstrated that individual heterozygosity was not associated with breeding success in captivity but was negatively associated with litter sizes of breeding females [174].

The correct selection of an appropriate sample size for population genetics research seems to be a neglected issue. Determination of the optimal level of sampling effort required for adequate characterization of the intraspecies genetic variation is of fundamental importance [175]. Too many samples than required for accurate estimation of genetic diversity increases costs and workload and lengthens the analysis, whereas too small a sample size results in significant errors in estimating 
the genetic diversity [176-178]. Particular sensitivity of mtDNA and microsatellite markers to sample sizes in addressing questions related to interpopulation genetic diversity, phylogenetics, and phylogeography leads to recommendations of using genomic data over microsatellites or a limited number of mitochondrial or/and nuclear single nucleotide polymorphism markers for genetic studies [175,179-181]. The limited availability of samples for genomic studies on M. lutreola also needs to be further investigated, as sampling size may be a significant limitation of genomics in conservation [166].

In future research on the genetic diversity of the surviving European mink populations, much more attention should be paid to optimization of the sample size, as sampling many individuals per population but using a small number of genetic markers does not contribute to accurate and reliable results [178,182]. Genomics offers a solution: Genome-wide techniques, such as restriction site-associated DNA sequencing (RAD-seq), to acquire a large number of single nucleotide polymorphisms (SNPs), allowing finer identification of population structure and stronger determination of patterns of isolation-by-distance than with microsatellites, with a smaller sample size [164,183]. The need to address the small number of available samples is crucial given the declining wild populations of European mink. Obtaining genetic samples from the rediscovered, relic wild populations of the species in the Dniester Delta in Ukraine is also important as a completely recently rediscovered Caucasian population or a presumptive Carpathian population $[2,184,185]$. The application of eDNA-based species detection is promising in rediscovery research projects.

Based on the analysis of the research work completed to-date in the field of M. lutreola genetics, the following research issues remaining to be addressed and resolved are as follows:

Research Issues Per Se:

1. Establishing a karyotype reference standard;

2. Initiation and completion of the whole-genome sequencing project (an improved scaffolded genome of M. putorius GenBank assembly accession GCA_902207235.1, and a platinum quality genome available for M. erminea, RefSeq assembly accession GCF_009829155.1, could be used for reference-based assembly or designing primers for any genomic location for targeted sequencing);

3. Development of a genome-scale (mitogenome-scale) SNPs panel, optimal for the study of interand intrapopulation genetic diversity, and the species phylogeny (possible revision of taxonomic status at the genus level) and phylogeography.

Conservation Issues:

4. Resolving the issue of undertaking conservation actions (including translocations) of wild persisting populations (scientifically-informed decisions regarding whether to treat them as a single or separate management units, which is especially relevant given the plans for the inclusion of the Spanish breeding program in the EEP program and plans for obtaining new founders from the wild Romanian population [12,164]);

5. Assessment of the impact of the breeding process on the development of traits essential for survival in the wild (adaptation to captivity) and the role of (re)introduced individuals in shaping the gene pools of wild populations (potential outbreeding and loss of unique adaptations, which could be assessed using captive-breeding experiments, in which individuals from distinct populations are hybridized to check if a loss of fitness is occurring);

6. Phylogeographic reconstruction in terms of origin of the French-Spanish population.

Promotional and Organizational Issues:

7. Encouraging the scientific community to undertake research related to European mink genetics, as well as its promotion and popularization (e.g., in the context of scientific social responsibility (SSR));

8. Scientific cooperation and networking (including sharing experiences, sharing samples, mentorship, and transfer of research results to conservation practice); 
9. Development of protocols for the preservation and biobanking of the species' genetic resources, which could be based on the extensive achievements and experience in this field with the Black-footed ferret $[12,117,143]$.

Maran et al. [12] listed the molecular genetic studies linked to the long-term management plan for European mink aiming to (1) determine if the population introduced onto Hiiumaa Island (Estonia) is in need of genetic supplementation in the coming years, (2) study the genetic diversity of the founders originating from the Western European population and the wild Eastern European population to determine whether this follows the same pattern found in earlier studies, and (3) encourage interest in the genome sequencing of European mink.

The question of the potential influence of reduced genetic diversity (e.g., in terms of MHC [50]) on the viability and survival of the wild and reintroduced populations also remains unresolved. Research initiatives should be undertaken to help resolve how genome alteration in each demographic influences M. lutreola species viability in a global change scenario [125,164].

Just as important as experimental research are reviews and (meta-)analytical works that indicate how gained genetic knowledge can be used to solve specific problems facing the conservation of M. lutreola, thereby indicating the application value of this knowledge.

The initiative to establish the European Mink Centre (www.europeanminkcentre.org) is worth mentioning; an internet platform, acting as a digital repository, information hub, and think tank dedicated to conservation biology, including conservation genetics, of the species [186]. The Centre's aim is to stimulate and facilitate research in the field of M. lutreola conservation genetics [186]. The promotion of the achievements of conservation genetics is of particular importance in the European mink case, as the success of the implemented conservation measures depends to a large extent on the favor of decision-makers and the general public. Hence, initiatives such as the European Mink Day proposed in 2015 by the Polish Society for Conservation Genetics LUTREOLA on 31 March may have an indirect and positive impact on creating research interest in M. lutreola and implementation of genetic research results in its conservation [187].

Funding: This research received no external funding.

Acknowledgments: The author thanks the two anonymous reviewers whose comments and suggestions helped improve and clarify this manuscript.

Conflicts of Interest: The author declares no conflict of interest.

\section{References}

1. Maran, T. Conservation Biology of European mink, Mustela Lutreola (Linnaeus 1761): Decline and Causes of Extinction. Ph.D. Thesis, Tallinn University, Tallinn, Estonia, 2007.

2. Maran, T.; Skumatov, D.; Gomez, A.; Põdra, M.; Abramov, A.V.; Dinets, V. Mustela lutreola, 2016. The IUCN Red List of Threatened Species 2016. Available online: https://www.iucnredlist.org/species/14018/45199861; http://dx.doi.org/10.2305/IUCN.UK.2016-1.RLTS.T14018A45199861.en (accessed on 12 September 2020).

3. Harrington, L.A.; Põdra, M.; Gómez, A.; Maran, T. Raising awareness of the plight of the critically endangered European mink in Spain is not miscommunication: A response to Melero. Biodivers. Conserv. 2018, 27, 269-271. [CrossRef]

4. Maran, T. European mink: Setting of goal for conservation and Estonian case study. Galemys 2003, 15, 1-11.

5. Witkowski, Z.J.; Król, W.; Solarz, W. (Eds.) Carpathian List of Endangered Species; WWF and Institute of Nature Conservation: Vienna, Austria; Polish Academy of Sciences: Kraków, Poland, 2003; p. 25.

6. NCBI-National Center for Biotechnology Information. Available online: https://www.ncbi.nlm.nih.gov/ (accessed on 15 September 2020).

7. Michaux, J.R.; Libois, R.; Davison, A.; Chevret, P.; Rosoux, R. Is the western population of the European mink, (Mustela lutreola), a distinct Management Unit for conservation? Biol. Conserv. 2004, 15, 357-367. [CrossRef]

8. Michaux, J.R.; Hardy, O.J.; Justy, F.; Fournier, P.; Kranz, A.; Cabria, M.; Davison, A.; Rosoux, R.; Libois, R. Conservation genetics and population history of the threatened European mink Mustela lutreola, with an emphasis on the west European population. Mol. Ecol. 2005, 14, 2373-2388. [CrossRef] [PubMed] 
9. Cabria, M.T.; Gonzalez, E.G.; Gómez-Moliner, B.J.; Zardoya, R. Microsatellite markers for the endangered European mink (Mustela lutreola) and closely related mustelids. Mol. Ecol. Notes 2007, 7, 1185-1188. [CrossRef]

10. Arthur, C.; Aulagnier, S.; des Neiges de Bellefroid, M.; Delas, G.; Fournier, P.; Gourreau, J.-M.; Lodé, T.; Michaux, J.; Rosoux, R.; Ruette, S. Deuxième Plan National de Restauration du Vison d'Europe (Mustela lutreola) 2007-2011; Ministère de 1'Ecologie, du Développement et de 1'Aménagement Durables: Paris, France, 2007; pp. 1-102.

11. Zuberogoitia, I.; Põdra, M.; Palazón, S.; Gómez, A.; Zabala, N.; Zabala, J. Misleading interpretation of shifting baseline syndrome in the conservation of European mink. Biodivers. Conserv. 2016, 25, 1795-1800. [CrossRef]

12. Maran, T.; Fienieg, E.; Schad, K. Long-Term Management Plan for European Mink (Mustela lutreola) European Endangered Species Programme (EEP); Tallinn Zoo and European Association of Zoos: Tallinn, Estonia; Amsterdam, The Netherlands, 2017; pp. 1-46.

13. Gilpin, M.E.; Soulé, M.E. Minimum viable populations: Processes of extinction. In Conservation Biology: The Science of Scarcity and Diversity; Soulé, M.E., Ed.; Sinauer Associates: Sunderland, UK, 1986; pp. 19-34.

14. Lodé, T. Genetic bottleneck in the threatened western population of European mink Mustela lutreola. Ital. J. Zool. 1999, 66, 351-353. [CrossRef]

15. Lodé, T.; Peltier, D. Genetic neighbourhood and effective population size in the endangered European mink Mustela lutreola. Biodivers. Conserv. 2005, 14, 251-259. [CrossRef]

16. Volobuev, V.T.; Ternovsky, D.V. Comparative study of karyotypes of the European and American minks (Lutreola lutreola L. Vison). Zool. Zhurnal 1974, 53, 1579-1580.

17. Volobuev, V.T.; Graphodatsky, A.S.; Ternovsky, D.V. Comparative karyotype studies in European and American minks (Carnivora-Mustelidae). Mamm. Chromosom. Newsl. 1974, 15, 6-7.

18. Graphodatsky, A.S.; Volobuev, V.T.; Ternovsky, D.V.; Radjabli, S.I. G-staining of chromosomes of seven mustelid species (Carnivora Mustelidae). Zool. Zhurnal 1976, 55, 1704-1711.

19. Graphodatsky, A.S.; Ternovsky, D.V.; Isaenko, A.A.; Radhzabli, S.I. Constitutive heterochromatin and DNA content in some mustelidae (Mustelidae Carnivora). Genetika 1977, 13, 2123-2128.

20. Graphodatsky, A.S.; Radjabli, S.I. Nucleolar organizer regions in chromosomes of nine species of mustelids. Dokl. Akad. Nauk SSSR 1980, 255, 1487-1489.

21. O’Brien, S.J.; Womack, J.E.; Lyons, L.A.; Moore, K.J.; Jenkins, N.A.; Copeland, N.G. Anchored reference loci for comparative genome mapping in mammals. Nat. Genet. 1993, 3, 103-112. [CrossRef] [PubMed]

22. Hosoda, T.; Suzuki, H.; Harada, M.; Tsuchiya, K.; Han, S.H.; Zhang, Y.; Kryukov, A.P.; Lin, L.K. Evolutionary trends of the mitochondrial lineage differentiation in species of genera Martes and Mustela. Genes Genet. Syst. 2000, 75, 259-267. [CrossRef] [PubMed]

23. Kurose, N.; Masuda, R.; Aoi, T.; Watanabe, S. Karyological differentiation between two closely related mustelids the Japanese weasel Mustela itatsi and the Siberian weasel Mustela siberica. Caryologia 2000, 53, 269-275. [CrossRef]

24. Sato, J.J.; Hosoda, T.; Wolsan, M.; Tsuchiya, K.; Yamamoto, M.; Suzuki, H. Phylogenetic relationships and divergence times among mustelids (Mammalia: Carnivora) based on nucleotide sequences of the nuclear interphotoreceptor retinoid binding protein and mitochondrial cytochrome $b$ genes. Zool. Sci. 2003, 20, 243-264. [CrossRef]

25. Marmi, J.; López-Giráldez, J.F.; Domingo-Roura, X. Phylogeny, evolutionary history and taxonomy of the Mustelidae based on sequences of the cytochrome $b$ gene and a complex repetitive flanking region. Zool. Scr. 2004, 33, 481-499. [CrossRef]

26. Koepfli, K.P.; Deere, K.A.; Slater, G.J.; Begg, C.; Begg, K.; Grassman, L.; Lucherini, M.; Veron, G.; Wayne, R.K. Multigene phylogeny of the Mustelidae: Resolving relationships tempo and biogeographic history of a mammalian adaptive radiation. BMC Biol. 2008, 6, 10. [CrossRef]

27. Gómez-Moliner, B.; Cabria, M.; Rubines, J.; Garin, I.; Madeira, M.; Elejalde, M.A.; Aihartza, J.; Fournier, P.; Palazón, S. PCR-RFLP identification of mustelid species: European mink (Mustela lutreola), American mink (M. vison) and polecat (M. putorius) by analysis of excremental DNA. J. Zool. 2004, 262, 311-316. [CrossRef]

28. Davison, A.; Griffiths, H.I.; Brookes, R.C.; Maran, T.; Macdonald, D.W.; Sidorovich, V.E.; Kitchener, A.C.; Irizar, I.; Villate, I.; González-Esteban, J.; et al. Mitochondrial DNA and palaeontological evidence for the origins of endangered European mink, Mustela lutreola. Anim. Conserv. 2000, 3, 345-355. [CrossRef] 
29. Cabria, M.T. Desarrollo y Aplicacion de Marcadores Moleculares para el Studio de la Biologia y la Conservacion del Vison Europeo Mustela lutreola (Linnaeus 1761). Ph.D. Thesis, Universidad del País Vasco, Leioa, Spain, 2009.

30. Cabria, M.T.; Gonzalez, E.G.; Gomez-Moliner, B.J.; Michaux, J.R.; Skumatov, D.; Kranz, A.; Fournier, P.; Palazon, S.; Zardoya, R. Patterns of genetic variation in the endangered European mink (Mustela lutreola L., 1761). BMC Evol. Biol. 2015, 15, 141. [CrossRef] [PubMed]

31. Flynn, J.J.; Finarelli, J.A.; Zehr, S.; Hsu, J.; Nedbal, M.A. Molecular phylogeny of the carnivora (mammalia): Assessing the impact of increased sampling on resolving enigmatic relationships. Syst. Biol. 2005, 54, 317-337. [CrossRef] [PubMed]

32. Skorupski, J.; Panicz, R.; Śmietana, P.; Napora-Rutkowski, Ł.; Soroka, M.; Kolek, L.; Budniak, M.; Wasowicz, B.; Keszka, S.; Kempf, M.; et al. Conservation Genetics in Poland-Theory and Practice; Polish Society for Conservation Genetics LUTREOLA \& Faculty of Biology, University of Szczecin: Szczecin, Poland, 2017; pp. 13-15, 197-204.

33. Gherman, C.M.; Sándor, A.D.; Kalmár, Z.; Marinov, M.; Mihalca, A.D. First report of Borrelia burgdorferi sensu lato in two threatened carnivores: The marbled polecat, Vormela peregusna and European mink, Mustela lutreola (Mammalia: Mustelidae). BMC Vet. Res. 2012, 8, 137. [CrossRef]

34. Bodewes, R.; Ruiz-Gonzalez, A.; Schapendonk, C.M.E.; van den Brand, J.M.A.; Osterhaus, A.D.M.E.; Smits, S.L. Viral metagenomic analysis of feces of wild small carnivores. Virol. J. 2014, 11, 89. [CrossRef]

35. Leimann, A.; Knuuttila, A.; Maran, T.; Vapalahti, O.; Saarma, U. Molecular epidemiology of Aleutian mink disease virus (AMDV) in Estonia, and a global phylogeny of AMDV. Virus Res. 2015, 199, 56-61. [CrossRef]

36. Damas, J.; Hughes, G.M.; Keough, K.C.; Painter, C.A.; Persky, N.S.; Corbo, M.; Hiller, M.; Koepfli, K.-P.; Pfenning, A.R.; Zhao, H.; et al. Broad host range of SARS-CoV-2 predicted by comparative and structural analysis of ACE2 in vertebrates. Proc. Natl. Acad. Sci. USA 2020, 117, 22311-22322. [CrossRef]

37. Frankham, R.; Ballou, J.D.; Briscoe, D.A. A Primer of Conservation Genetics; Cambridge University Press: Cambridge, UK, 2004.

38. Youngman, P.M. A Bibliography of Mustelids; Part IX: European Mink. Syllogeus 66; Canadian Museum of Nature: Ottawa, ON, Canada, 1991.

39. Graphodatsky, A.S. Mustela lutreola (European Mink). In Atlas of Mammalian Chromosomes; O’Brien, S.J., Menninger, J.C., Nash, W.G., Eds.; John Wiley \& Sons: Hoboken, NJ, USA, 2006; p. 487.

40. Franco-de-Sá, J.F.O.; Rosas, F.C.W.; Feldberg, E. Cytogenetic study of the giant otter Pteronura brasiliensis Zimmermann 1780 (Carnivora Mustelidae Lutrinae). Genet. Mol. Biol. 2007, 30, 1093-1096. [CrossRef]

41. Ewer, R.F. The Carnivores; Cornell University Press: New York, NY, USA, 1973.

42. Kurose, N.; Abramov, A.V.; Masuda, R. Molecular phylogeny and taxonomy of the genus Mustela (Mustelidae Carnivora) inferred from mitochondrial DNA sequences: New perspectives on phylogenetic status of the back-striped weasel and American mink. Mamm. Study 2008, 33, 25-33. [CrossRef]

43. Graphodatsky, A.S.; Yang, F.; Serdukova, N.; Perelman, P.; Zhdanova, N.S.; Ferguson-Smith, M.A. Dog chromosome-specific paints reveal evolutionary inter- and intrachromosomal rearrangements in the American mink and human. Cytogenet. Cell Genet. 2000, 90, 275-278. [CrossRef]

44. Graphodatsky, A.S.; Yang, F.; Perelman, P.; O’Brien, P.C.M.; Serdukova, N.A.; Milne, B.S.; Biltueva, L.S.; Fu, B.; Vorobieva, N.V.; Kawada, S.I.; et al. Comparative molecular cytogenetic studies in the order Carnivora: Mapping chromosomal rearrangements onto the phylogenetic tree. Cytogenet. Genome Res. 2002, 96, 137-145. [CrossRef] [PubMed]

45. Peltier, D.; Lodé, T. Molecular survey of genetic diversity in the endangered European mink Mustela lutreola. C R Biol. 2003, 325, S49-S53. [CrossRef]

46. López-Giráldez, F.; Gómez-Moliner, B.J.; Marmi, J.; Domingo-Roura, X. Genetic distinction of American and European mink (Mustela vison and M. lutreola) and European polecat (M. putorius) hair samples by detection of a species-specific SINE and a RFLP assay. J. Zool. 2005, 265, 405-410. [CrossRef]

47. Cabria, M.T.; Michaux, J.R.; Gómez-Moliner, B.J.; Skumatov, D.; Maran, T.; Fournier, P.; López de Luzuriaga, J.; Zardoya, R. Bayesian analysis of hybridization and introgression between the endangered european mink (Mustela lutreola) and the polecat (Mustela putorius). Mol. Ecol. 2011, 20, 1176-1190. [CrossRef] [PubMed]

48. Veale, A.J.; Clout, M.N.; Gleeson, D.M. Genetic population assignment reveals a long-distance incursion to an island by a stoat (Mustela erminea). Biol. Invasions 2012, 14, 735-742. [CrossRef] 
49. Lodé, T.; Guiral, G.; Peltier, D. European mink-polecat hybridization events: Hazards from natural process? J. Hered. 2005, 96, 1-8. [CrossRef] [PubMed]

50. Becker, L.; Nieberg, C.; Jahreis, K.; Peters, E. MHC class II variation in the endangered European mink Mustela lutreola (L. 1761)—Consequences for species conservation. Immunogenetics 2009, 61, 281-288. [CrossRef]

51. Nishita, Y.; Abramov, A.V.; Kosintsev, P.A.; Lin, L.K.; Watanabe, S.; Yamazaki, K.; Kaneko, Y.; Masuda, R. Genetic variation of the MHC class II DRB genes in the Japanese weasel, Mustela itatsi, endemic to Japan, compared with the Siberian weasel, Mustela sibirica. Tissue Antigens 2015, 86, 431-442. [CrossRef]

52. Nishita, Y.; Kosintsev, P.A.; Haukisalmi, V.; Väinölä, R.; Raichev, G.G.; Murakami, T.; Abramov, A.V.; Kaneko, Y.; Masuda, R. Diversity of MHC class II DRB alleles in the Eurasian population of the least weasel, Mustela nivalis (Mustelidae: Mammalia). Biol. J. Linn. Soc. 2017, 121, 28-37. [CrossRef]

53. Mouton, A.; Fournier-Chambrillon, C.; Fournier, P.; Marchand, I.; Urra Maya, F.; Michaux, J. Genomics and European mink: A new avenue for the species' conservation? In Proceedings of the 4th Annual Meeting in Conservation Genetics 2020_From Genomes to Application; von Thaden, A., Nowak, C., Prost, S., Eds.; Senckenberg Research Institute and Natural History Museum Frankfurt am Main: Frankfurt, Germany, 2020; p. 100.

54. GenBank (NCBI). Available online: https://www.ncbi.nlm.nih.gov/genbank/ (accessed on 15 September 2020).

55. Lushnikova, T.P.; Grafodatskiü, A.S.; Romashchenko, A.G.; Radzhabli, S.I. Chromosomal localization and evolutionary age of satellite DNAs of Mustelidae. Genetika 1988, 24, 2134-2140.

56. Lushnikova, T.P.; Grafodatskiy, A.S.; Ivanov, S.V.; Romashchenko, A.G.; Ternovskiy, L.V.; Ternovskaya, I.G.; Radzhabli, S.I. EcoRI- and BamHI-families of repeated sequences in mustelids. Genetika 1989, 25, 1449-1461. [PubMed]

57. Lushnikova, T.P.; Omelyanchuk, L.V.; Graphodatsky, A.S.; Radjabli, S.I.; Ternovskaya, Y.G.; Ternovsky, D.V. Phylogenetic relationships of closely related species (Mustelidae). Interspecific variability of blot-hybridization patterns of BamHI repeats. Genetika 1989, 25, 1089-1094. [PubMed]

58. Peng, X.; Alföldi, J.; Gori, K.; Eisfeld, A.J.; Tyler, S.R.; Tisoncik-Go, J.; Brawand, D.; Law, G.L.; Skunca, N.; Hatta, M.; et al. The draft genome sequence of the ferret (Mustela putorius furo) facilitates study of human respiratory disease. Nat. Biotechnol. 2014, 32, 1250-1255. [CrossRef] [PubMed]

59. Zhang, Z.; Schwartz, S.; Wagner, L.; Miller, W. A greedy algorithm for aligning DNA sequences. J. Comput. Biol. 2000, 7, 203-214. [CrossRef]

60. Skorupski, J.; University of Szczecin: Szczecin, Poland. Personal communication, 2019.

61. Oliveira, R.; Castro, D.; Godinho, R.; Luikart, G.; Alves, P.C. Species identification using a small nuclear gene fragment: Application to sympatric wild carnivores from South-western Europe. Conserv. Genet. 2010, 11, 1023-1032. [CrossRef]

62. The Vincent Wildlife Trust. Available online: https://www.vwt.org.uk/species/european-mink/ (accessed on 15 September 2020).

63. European Mink Project-Wildlife Conservation Research Unit. Available online: https://www.wildcru.org/ research/european-mink-project/ (accessed on 15 September 2020).

64. Sidorovich, V.E.; Kruuk, H.; Macdonald, D.W. Body size, and interactions between European and American mink (Mustela lutreola and M. vison) in Eastern Europe. J. Zool. 1999, 248, 521-527. [CrossRef]

65. Fournier, P.; Maizeret, C.; Jimenez, D.; Chusseau, J.-P.; Aulagnier, S.; Spitz, F. Habitat utilization by sympatric European mink Mustela lutreola and polecats Mustela putorius in south-western France. Acta Theriol. 2007, 52, 1-12. [CrossRef]

66. Maran, T.; Põdra, M.; Harrington, L.A.; Macdonald, D.W. European mink: Restoration attempts for a species on the brink of extinction. In Biology and Conservation of Musteloids; Macdonald, D.W., Newman, C., Harrington, L.A., Eds.; Oxford University Press: Oxford, UK, 2017; pp. 370-388. [CrossRef]

67. Põdra, M.; Gómez, A. Rapid expansion of the American mink poses a serious threat to European mink in Spain. Mammalia 2018, 82, 1-9. [CrossRef]

68. Domingo-Roura, X. Genetic distinction of marten species by the fixation of a microsatellite region. J. Mammal. 2002, 83, 907-912. [CrossRef]

69. Monterroso, P.; Godinho, R.; Oliveira, T.; Ferreras, P.; Kelly, M.J.; Morin, D.J.; Waits, L.P.; Alves, P.C.; Mills, L.S. Feeding ecological knowledge: The underutilised power of faecal DNA approaches for carnivore diet analysis. Mam. Rev. 2019, 49, 97-112. [CrossRef] 
70. Kiseleva, N.V.; Sorokin, P.A. Study of the distribution of Mustelids over the Southern Urals Using Noninvasive Methods. Contemp. Probl. Ecol. 2013, 6, 300-305. [CrossRef]

71. Fernandes, C.A.; Ginja, C.; Pereira, I.; Tenreiro, R.; Bruford, M.W.; Santos-Reis, M. Species-specific mitochondrial DNA markers for identification of non-invasive samples from sympatric carnivores in the Iberian Peninsula. Conserv. Genet. 2008, 9, 681-690. [CrossRef]

72. Larson, S.; Jameson, R.; Bodkin, J.; Staedler, M.; Bentzen, P. Microsatellite DNA and mitochondrial DNA variation in remnant and translocated sea otter (Enhydra lutris) populations. J. Mammal. 2002, 83, 893-906. [CrossRef]

73. Marmi, J.; Lopez-Giraldez, F.; Macdonald, D.W.; Calafell, F.; Zholnerovskaya, E.; Domingo-Roura, X. Mitochondrial DNA reveals a strong phylogeographic structure in the badger across Eurasia. Mol. Ecol. 2006, 15, 1007-1020. [CrossRef] [PubMed]

74. Pertoldi, C.; Breyne, P.; Cabria, M.T.; Halfmaerten, D.; Jansman, H.A.H.; Van Den Berge, K.; Madsen, A.B.; Loeschcke, V. Genetic structure of the European polecat (Mustela putorius) and its implication for conservation strategies. J. Zool. 2006, 270, 102-115. [CrossRef]

75. Aguilar, A.; Jessup, D.A.; Estes, J.; Garza, J.C. The distribution of nuclear genetic variation and historical demography of sea otters. Anim. Conserv. 2008, 11, 35-45. [CrossRef]

76. Lecis, R.; Ferrando, A.; Ruiz-Olmo, J.; Mañas, S.; Domingo-Roura, X. Population genetic structure and distribution of introduced American mink (Mustela vison) in Spain based on microsatellite variation. Conserv. Genet. 2008, 9, 1149-1161. [CrossRef]

77. Lebarbenchon, C.; Poitevin, F.; Montgelard, C. Genetic variation of the weasel (Mustela nivalis) in Corsica based on mitochondrial control region sequences. Mamm. Biol. 2006, 71, 164-171. [CrossRef]

78. Frantz, A.C.; Pope, L.C.; Etherington, T.R.; Wilson, G.J.; Burke, T. Using isolation-by-distance-based approaches to assess the barrier effect of linear landscape elements on badger (Meles meles) dispersal. Mol. Ecol. 2010, 19, 1663-1674. [CrossRef]

79. Mucci, N.; Arrendal, J.; Ansorge, H.; Bailey, M.; Bodner, M.; Delibes, M.; Ferrando, A.; Fournier, P.; Fournier, C.; Godoy, J.A.; et al. Genetic diversity and landscape genetic structure of otter (Lutra lutra) populations in Europe. Conserv. Genet. 2010, 11, 583-599. [CrossRef]

80. Nei, M. Estimation of average heterozygosity and genetic distance from a small number of individuals. Genetics 1978, 89, 583-590. [PubMed]

81. Wright, S. Coefficients of inbreeding and relationships. Am. Nat. 1992, 56, 330-338. [CrossRef]

82. Ma, L.; Ji, Y.-J.; Zhang, D.-X. Statistical measures of genetic differentiation of populations: Rationales, history and current states. Curr. Zool. 2015, 61, 886-896. [CrossRef]

83. Korablev, M.P.; Korablev, P.N.; Korablev, N.P.; Tumanov, I.L. Polymorphism of the Endangered European Mink (Mustela lutreola, Carnivora, Mustelidae) Population in the Central Forest Reserve and Neighboring Areas. Biol. Bull. Russ. Acad. Sci. 2014, 41,1-9. [CrossRef]

84. Korablev, N.P.; Korablev, M.P.; Korablev, P.N. Phene pool dynamics as an index of mortality in commercial mammal species. In Theriofauna of Russia and Neighboring Countries: Proceedings of the International Conference and IX Congress of the Theriological Society of Russian Academy of Sciences; KMK: Moscow, Russia, 2011; p. 243.

85. Lodé, T. Genetic heterozygosity in polecat Mustela putorius populations from western France. Hereditas 1998, 129, 259-261. [CrossRef]

86. Novikov, G.A. The European Mink; Izd. Leningradskogo Gos. Univ.: Leningrad, Russia, 1939.

87. Wilson, D.E.; Reeder, D.M. (Eds.) Mammal Species of the World. A Taxonomic and Geographic Reference; Johns Hopkins University Press: Baltimore, MA, USA, 2005.

88. Clavero, M. Shifting baselines and the conservation of non-native species. Conserv. Biol. 2014, 28, 1434-1436. [CrossRef]

89. Carbonell, R. Managing Spanish European mink populations: Moving from a precautionary approach towards knowledge-based management. J. Nat. Conserv. 2015, 25, 58-61. [CrossRef]

90. Clavero, M. Non-Native species as conservation priorities: Response to Díez-León et al. Conserv. Biol. 2015, 29, 957-959. [CrossRef]

91. Díez-León, M.; Miranda, R.; Ariño, A.H.; Galicia, D. Setting priorities for existing conservation needs of crayfish and mink. Conserv. Biol. 2015, 29, 599-601. [CrossRef]

92. Melero, Y. Communication of flagship species in conservation: Lessons from invasive management projects. Biodivers. Conserv. 2017, 26, 2973-2978. [CrossRef] 
93. Zuberogoitia, I.; Põdra, M.; Palazón, S.; Gómez, A.; Zabala, N.; Zabala-Albizua, J. Facing Extinction, Last Call for the European Mink. Ann. Rev. Resear. 2018, 2, 555581.

94. Davison, A.; Birks, J.D.S.; Griffiths, H.I.; Kitchener, A.C.; Biggins, D.; Butlin, R.K. Hybridization and the phylogenetic relationship between polecats and domestic ferrets in Britain. Biol. Conserv. 1999, 87, $155-161$. [CrossRef]

95. Abramov, A.V.; Meschersky, I.G.; Aniskin, V.M.; Rozhnov, V.V. The mountain weasel Mustela kathiah (Carnivora: Mustelidae): Molecular and Karyological data. Biol. Bull. Russ. Acad. Sci. 2013, 40, 52-60. [CrossRef]

96. Yonezawa, T.; Nikaido, M.; Kohno, M.; Fukumoto, Y.; Okada, N.; Hasegawa, M. Molecular phylogenetic study on the origin and evolution of Mustelidae. Gene 2007, 396, 1-12. [CrossRef]

97. Sato, J.J.; Hosada, T.; Wolsan, M.; Suzuki, H. Molecular phylogeny of Arctoids (Mammalia: Carnivora) with emphasis on phylogenetic and taxonomic positions of the ferret-badgers and skunks. Zool. Sci. 2004, 21, 111-118. [CrossRef]

98. Fulton, T.L.; Strobeck, C. Molecular phylogeny of the Arctoidea (Carnivora): Effect of missing data on supertree and supermatrix analyses of multiple gene data sets. Mol. Phylogenet. Evol. 2006, 41, 165-181. [CrossRef]

99. Abramov, A.V. A taxonomic review of the genus Mustela (Mammalia Carnivora). Zoosyst. Ross. 2000, 8, 357-364.

100. Harding, L.E.; Smith, F.A. Mustela or Vison? Evidence for the taxonomic status of the American mink and a distinct biogeographic radiation of American weasels. Mol. Phylogenet. Evol. 2009, 52, 632-642. [CrossRef]

101. Rowe, G.; Sweet, M.; Beebee, T.J.C. An Introduction to Molecular Ecology, 3rd ed.; Oxford University Press: Oxford, UK, 2017; p. 1.

102. Mañas, S.; Ceña, J.C.; Ruiz-Olmo, J.; Palazón, S.; Domingo, M.; Wolfinbarger, J.B.; Bloom, M.E. Aleutian mink disease parvovirus in wild riparian carnivores in Spain. J. Wildl. Dis. 2001, 37, 138-144. [CrossRef] [PubMed]

103. Moinet, M. Etude Comparative de la Leptospirose Chez le Vison d'Europe (Mustela lutreola) et les Autres Petits Carnivores Sauvages du Sud-Ouest de la France. Ph.D. Thesis, Ecole Nationale Veterinaire de Nantes, Nantes, France, 2008.

104. Padgett-Stewart, T.M.; Wilcox, T.M.; Carim, K.J.; McKelvey, K.S.; Young, M.K.; Schwartz, M.K. An eDNA assay for river otter detection: A tool for surveying a semi-aquatic mammal. Conserv. Genet. Resour. 2016, 8, 5-7. [CrossRef]

105. Sales, N.; Mckenzie, M.; Drake, J.; Harper, L.; Browett, S.; Coscia, I.; Wangensteen, O.; Baillie, C.; Bryce, E.; Dawson, D.; et al. Fishing for mammals: Landscape-level monitoring of terrestrial and semi-aquatic communities using eDNA from riverine systems. J. Appl. Ecol. 2020, 57, 707-716. [CrossRef]

106. Witzenberger, K.A.; Hochkirch, A. Ex situ conservation genetics: A review of molecular studies on the genetic consequences of captive breeding programmes for endangered animal species. Biodivers. Conserv. 2011, 20, 1843-1861. [CrossRef]

107. Attard, C.R.; Möller, L.M.; Sasaki, M.; Hammer, M.P.; Bice, C.M.; Brauer, C.J.; Carvalho, D.C.; Harris, J.O.; Beheregaray, L.B. A novel holistic framework for genetic-based captive-breeding and reintroduction programs. Conserv. Biol. 2016, 30, 1060-1069. [CrossRef] [PubMed]

108. Amstislavsky, S.; Lindeberg, H.; Aalto, J.; Kennedy, M.W. Conservation of European mink (Mustela lutreola): Focus on reproduction and reproductive technologies. Reprod. Domest. Anim. 2008, 43, 502-513. [CrossRef] [PubMed]

109. Ryder, O. Species conservation and systematics: The dilemma of subspecies. Trends Ecol. Evol. 1986, 1, 9-10. [CrossRef]

110. Lynch, M. The genetic interpretation of inbreeding depression and outbreeding depression. Evolution 1991, 45, 622-629. [CrossRef]

111. Fraser, D.; Bernatchez, L. Adaptive evolutionary conservation: Towards a unified concept for defining conservation units. Mol. Ecol. 2001, 10, 2741-2752. [CrossRef]

112. Saveljev, A.P. Concepts Useful in Management and Conservation of Wildlife Population. Vestn. Udmurt. Univ. 2009, 1, 73-79.

113. Gippoliti, S. Captive breeding and conservation of European mammal diversity. Hystrix 2004, 15, 35-53. [CrossRef] 
114. Wisely, S.; McDonald, D.; Buskirk, S. Evaluation of the genetic management of the endangered black-footed ferret (Mustela nigripes). Zoo Biol. 2003, 22, 287-298. [CrossRef]

115. Wisely, S.M.; Santymire, R.M.; Livieri, T.M.; Mueting, S.A.; Howard, J.-G. Genotypic and phenotypic consequences of reintroduction history in the black-footed ferret (Mustela nigripes). Conserv. Genet. 2008, 9, 389-399. [CrossRef]

116. Cain, C.M.; Livieri, T.M.; Swanson, B.J. Genetic evaluation of a reintroduced population of black-footed ferrets (Mustela nigripes). J. Mamm. 2011, 92, 751-759. [CrossRef]

117. Wisely, S.M.; Ryder, O.A.; Santymire, R.M.; Engelhardt, J.F.; Novak, B.J. A Road Map for 21st Century Genetic Restoration: Gene Pool Enrichment of the Black-Footed Ferret. J. Hered. 2015, 106, 581-592. [CrossRef] [PubMed]

118. Lodé, T. The European Mink's Paradox: Near Extinction but Colonizing New Habitats. JSM Biol. 2017, 2, 1011.

119. Excoffier, L.; Foll, M.; Petit, R. Genetic Consequences of Range Expansions. Annu. Rev. Ecol. Evol. Syst. 2009, 40, 481-501. [CrossRef]

120. Cornuet, J.M.; Luikart, G. Description and Power Analysis of Two Tests for Detecting Recent Population Bottlenecks from Allele Frequency Data. Genetics 1996, 144, 2001-2014.

121. Dlugosch, K.M.; Parker, I.M. Founding events in species invasions: Genetic variation, adaptive evolution, and the role of multiple introductions. Mol. Ecol. 2008, 17, 431-449. [CrossRef]

122. Palazón, S.; Melero, Y. Status, threats and management actions on the European mink Mustela lutreola (Linnaeus, 1761) in Spain: A review of the studies performed since 1992. Munibe Monogr. Nat. Ser. 2014, 3, 109-115. [CrossRef]

123. Del Molino, D.; Sánchez-Barreiro, D.; Barnes, F.; Gilbert, I.; Love, M.D. Quantifying Temporal Genomic Erosion in Endangered Species. Trends Ecol. Evol. 2018, 33, 176-185. [CrossRef]

124. Lopez, L.; Turner, K.G.; Bellis, E.S.; Lasky, J.R. Genomics of natural history collections for understanding evolution in the wild. Mol. Ecol. Resour. 2020, 20, 1153-1160. [CrossRef]

125. US Fish; Wildlife Service; National Fisheries Service. Policy Regarding the Recognition of Distinct Vertebrate Population Segments under the Endangered Species; Act Federal Register; U.S. Government Publishing Office: Washington, DC, USA, 1996; Volume 61, pp. 4721-4725.

126. Wright, S. Evolution in Mendelian populations. Genetics 1931, 16, 97-159. [PubMed]

127. Kimura, M. Random genetic drift in multi-allelic locus. Evolution 1955, 9, 419-435. [CrossRef]

128. Wright, S. Evolution and the Genetics of Populations. In The Theory of Gene Frequencies; University of Chicago Press: Chicago, IL, USA, 1969; Volume 2.

129. Frankham, R. Effective population size/adult population size ratios in wildlife: A review. Genet. Res. 1995, 66, 95-107. [CrossRef]

130. Kiik, K.; Maran, T.; Nemvalts, K.; Sandre, S.L.; Tammaru, T. Reproductive parameters of critically endangered European mink (Mustela lutreola) in captivity. Anim. Reprod. Sci. 2017, 181, 86-92. [CrossRef] [PubMed]

131. Kiseleva, N.V. The Current State of the European Mink in Russia; Polish Society for Conservation Genetics LUTREOLA: Szczecin, Poland, 2018.

132. Ternovsky, D.V.; Ternovskaya, Y.G. Ecology of Mustelids; Nauka (Scientific Siberian Press): Novosibirsk, Russia, 1994.

133. Kiik, K.; Maran, T.; Nagl, A.; Ashford, K.; Tammaru, T. The causes of the low breeding success of European mink (Mustela lutreola) in captivity. Zoo Biol. 2013, 32, 387-393. [CrossRef] [PubMed]

134. Mañas, F.; Palazón, S.; Ruiz-Olmo, J.; Maran, T.; Festl, W.; Seebass, C. Captive Breeding Program of European Mink in Spain: El Centre de Port de Suert. In International Conference on the Conservation of the European Mink (Mustela lutreola)_Proceedings Book; Gobierno de La Roja: Logroño, Spain, 2006; pp. 123-129.

135. Maran, T.; Põdra, M.; Põlma, M.; Macdonald, D.W. The survival of captive-born animals in restoration programmes-Case study of the endangered European mink Mustela lutreola. Biol. Conserv. 2009, 142, 1685-1692. [CrossRef]

136. Kneidinger, N.; Nagl, A.; Kiik, K.; Schwarzenberger, F.; Maran, T. The individual courtship behaviour of male European mink (Mustela lutreola) is a good indicator for their breeding success. Appl. Anim. Behav. Sci. 2018, 205, 98-106. [CrossRef]

137. Van Oers, K.; de Jong, G.; van Noordwijk, A.J.; Kempenaers, B.; Drent, P.J. Contribution of genetics to the study of animal personalities: A review of case studies. Behaviour 2005, 142, 1185-1206. [CrossRef] 
138. Haage, M.; Maran, T.; Bergvall, U.A.; Elmhagen, B.; Angerbjörn, A. The influence of spatiotemporal conditions and personality on survival in reintroductions-evolutionary implications. Oecologia 2017, 183, 45-56. [CrossRef]

139. Amstislavsky, S.; Aalto, J.; Järvinen, M.; Lindeberg, H.; Valtonen, M.; Zudova, G.; Ternovskaya, Y. Transfer of European mink (Mustela lutreola) embryos into hybrid recipients. Theriogenology 2004, 62, 458-467. [CrossRef]

140. Amstislavsky, S.; Kizilova, E.; Ternovskaya, Y.; Zudova, G.; Lindeberg, H.; Aalto, J.; Valtonen, M. Embryo development and embryo transfer in the European mink (Mustela lutreola), an endangered mustelid species. Reprod. Fertil. Dev. 2006, 18, 459-467. [CrossRef] [PubMed]

141. Amstislavsky, S.; Lindeberg, H.; Aalto, J.; Järvinen, M.; Valtonen, M.; Kizilova, E.; Zudova, G.; Ternovskaya, Y. Embryo cryopreservation and transfer in Mustelidae: Approaches to ex situ conservation of the endangered European mink. Int. J. Refrig. 2006, 29, 396-402. [CrossRef]

142. Lin, C.; Tsai, S. The effect of cryopreservation on DNA damage, gene expression and protein abundance in vertebrate. Ital. J. Anim. Sci. 2012, 11, e21. [CrossRef]

143. Santymire, R. Implementing the use of a biobank in the endangered black-footed ferret (Mustela nigripes). Reprod. Fertil. Dev. 2016, 28, 1097-1104. [CrossRef] [PubMed]

144. Ehrlich, P.R. The loss of diversity: Causes and consequences. In Biodiversity; Wilson, E.O., Ed.; National Academy Press: Washington, DC, USA, 1988; pp. 21-27.

145. Howard, J.G.; Bush, M.; Morton, C.; Morton, F.; Wildt, D.E. Comparative semen cryopreservation in ferrets (Mustela putorius furo) and pregnancies after laparoscopic intrauterine insemination with frozen-thawed spermatozoa. J. Reprod. Fertil. 1991, 92, 109-118. [CrossRef]

146. Wisely, S.; Buskirk, S.; Fleming, M.; McDonald, D.; Ostrander, E. Genetic Diversity and Fitness in Black-Footed Ferrets before and during a Bottleneck. J. Hered. 2002, 93, 231-237. [CrossRef]

147. Wisely, S.M.; Santymire, R.M.; Marinari, P.E.; Kreeger, J.S.; Livieri, T.M.; Wildt, D.E.; Howard, J.G. Environment influences morphology and development of in situ and ex situ populations of the black-footed ferret. Anim. Conserv. 2005, 8, 321-328. [CrossRef]

148. Howard, J.G.; Wildt, D.E. Approaches and efficacy of artificial insemination in felids and mustelids. Theriogenology 2009, 71, 130-148. [CrossRef]

149. Howard, J.G.; Lynch, C.; Santymire, R.; Marinari, P.; Wildt, D.E. Recovery of gene diversity using long-term, cryopreserved spermatozoa in the endangered black-footed ferret. Anim. Conserv. 2016, 19, 102-111. [CrossRef]

150. WAZA (World Association of Zoos and Aquariums). Building a Future for Wildlife-The World Zoo and Aquarium Conservation Strategy; WAZA: Bern, Switzerland, 2005.

151. Hughes, A.L. MHC polymorphism and the design of captive breeding programs. Conserv. Biol. 1991, 5, 249-250. [CrossRef]

152. Tumanov, I.L.; Abramov, A.V. A study of the hybrids between the European Mink Mustela lutreola and the Polecat M. putorius. Small Carniv. Conserv. 2002, 27, 29-31.

153. Macdonald, D.W.; Sidorovich, V.E.; Maran, T.; Ktuuk, H. European Mink, Mustela lutreola: Analyses for Conservation; WildCRU and Darwin Initiative: Tubney, UK, 2002.

154. Allendorf, F.W.; Luikart, G.H.; Aitken, S.N. Conservation and the Genetics of Populations, 2nd ed.; Wiley-Blackwell: Oxford, UK, 2013.

155. Biebach, I.; Leigh, D.M.; Sluzek, K.; Keller, L.F. Genetic Issues in Reintroduction. In Reintroduction of Fish and Wildlife Populations; Jachowski, D.S., Millspaugh, J.J., Angermeier, P.L., Slotow, R., Eds.; University of California Press: Oakland, CA, USA, 2016; pp. 149-183.

156. Ognev, S.I. Mammals of Eastern Europe and Northern Asia: Carnivorous Mammals; Glavnauka: Moscow, Russia, 1931; Volume 2.

157. Heptner, V.G.; Naumov, N.P.; Yurgenson, P.B.; Sludskii, A.A.; Chirkova, A.F.; Bannikov, A.G. Mammals of the Soviet Union; Smithsonian Institution Libraries and The National Science Foundation: New Delhi, India, 2001; Volume 2(1b).

158. Rozhnov, V.V. Extinction of the European mink: Ecological catastrophe or a natural process? Lutreola 1993, $1,10-16$.

159. Ternovsky, D.V. The Biology of the Mustelids (Mustelidae); Nauka Publ.: Novosibirsk, USSR, 1977.

160. Allendorf, F.W.; Hohenlohe, P.A.; Luikart, G. Genomics and the future of conservation genetics. Nat. Rev. Genet. 2010, 11, 697-709. [CrossRef] [PubMed] 
161. Ouborg, N.J.; Pertoldi, C.; Loeschcke, V.; Bijlsma, R.; Hedrick, P.W. Conservation genetics in transition to conservation genomics. Trends Genet. 2010, 26, 177-187. [CrossRef]

162. Pertoldi, C.; Randi, E. The ongoing transition at an exponential speed from Conservation genetics to Conservation genomics. Gen. Biodiv. J. 2018, 2, 47-54.

163. Khan, S.; Nabi, G.; Ullah, M.; Yousaf, M.; Manan, S.; Siddique, R.; Hou, H. Overview on the Role of Advance Genomics in Conservation Biology of Endangered Species. Int. J. Genom. 2016, 2016, 1-8. [CrossRef]

164. Stronen, A.V.; Iacolina, L.; Ruiz-Gonzalez, A. Rewilding and conservation genomics: How developments in (re)colonization ecology and genomics can offer mutual benefits for understanding contemporary evolution. Glob. Ecol. Conserv. 2019, 17, e00502. [CrossRef]

165. Steiner, C.; Putnam, A.; Hoeck, P.; Ryder, O. Conservation Genomics of Threatened Animal Species. Annu. Rev. Anim. Biosci. 2013, 1, 261-281. [CrossRef]

166. Supple, M.A.; Shapiro, B. Conservation of biodiversity in the genomics era. Genome Biol. 2018, $19,131$. [CrossRef]

167. Wright, B.; Farquharson, K.A.; McLennan, E.A.; Belov, K.; Hogg, C.J.; Grueber, C.E. From reference genomes to population genomics: Comparing three reference-aligned reduced-representation sequencing pipelines in two wildlife species. BMC Genom. 2019, 20, 453. [CrossRef]

168. Fuentes-Pardo, A.P.; Ruzzante, D.E. Whole-genome sequencing approaches for conservation biology: Advantages, limitations and practical recommendations. Mol. Ecol. 2017, 26, 5369-5406. [CrossRef] [PubMed]

169. Brandies, P.; Peel, E.; Hogg, C.J.; Belov, K. The Value of Reference Genomes in the Conservation of Threatened Species. Genes 2019, 10, 846. [CrossRef] [PubMed]

170. Campana, M.G.; Parker, L.D.; Hawkins, M.T.; Young, H.S.; Helgen, K.M.; Gunther, M.S.; Woodroffe, R.; Maldonado, J.E.; Fleischer, R.C. Genome sequence, population history, and pelage genetics of the endangered African wild dog (Lycaon pictus). BMC Genom. 2016, 17, 1013. [CrossRef] [PubMed]

171. Ryder, O.A. Conservation genomics: Applying whole genome studies to species conservation efforts. Cytogenet. Genome Res. 2005, 108, 6-15. [CrossRef] [PubMed]

172. Wang, L.; Wu, J.; Liu, X.; Di, D.; Liang, Y.; Feng, Y.; Zhang, S.; Li, B.; Qi, X.-G. A high-quality genome assembly for the endangered golden snub-nosed monkey (Rhinopithecus roxellana). GigaScience 2019, 8, giz098. [CrossRef]

173. Van der Valk, T.; Gonda, C.M.; Silegowa, H.; Almanza, S.; Sifuentes-Romero, I.; Hart, T.B.; Hart, J.A.; Detwiler, K.M.; Guschanski, K.; Yoder, A. The Genome of the Endangered Dryas Monkey Provides New Insights into the Evolutionary History of the Vervets. Mol. Biol. Evol. 2020, 37, 183-194. [CrossRef]

174. Wright, B.R.; Farquharson, K.A.; McLennan, E.A.; Belov, K.; Hogg, C.J.; Grueber, C.E. A demonstration of conservation genomics for threatened species management. Mol. Ecol. Resour. 2020. [CrossRef]

175. Phillips, J.D.; Gillis, D.J.; Hanner, R.H. Incomplete estimates of genetic diversity within species: Implications for DNA barcoding. Ecol. Evol. 2019, 9, 2996-3010. [CrossRef]

176. Nazareno, A.G.; Jump, A.S. Species-genetic diversity correlations in habitat fragmentation can be biased by small sample sizes. Mol. Ecol. 2012, 21, 2847-2849. [CrossRef]

177. Willing, E.M.; Dreyer, C.; Oosterhout, C.V. Estimates of genetic differentiation measured by F $_{\mathrm{ST}}$ do not necessarily require large sample sizes when using many SNP markers. PLoS ONE 2012, 7, e42649. [CrossRef]

178. Hobas, S.; Gaggiotti, O.; Bertorelle, G. Sample planning optimization tool for conservation and population genetics (SPOTG): A software for choosing the appropriate number of markers and samples. Methods Ecol. Evol. 2013, 4, 299-303. [CrossRef]

179. Landguth, E.L.; Fedy, B.C.; Oyler-McCance, S.J.; Garey, A.L.; Emel, S.L.; Mumma, M.; Wanger, H.H.; Fortin, M.J.; Cushman, S.A. Effects of sample size, number of markers, and allelic richness on the detection of spatial genetic pattern. Mol. Ecol. Res. 2012, 12, 276-284. [CrossRef]

180. Peery, M.Z.; Kirby, R.; Reid, B.N.; Stoelting, R.; Doucet-Bëer, E.; Robinson, S.; Vásquez-Carrillo, C.; Pauli, J.N.; Palsbøll, P.J. Reliability of genetic bottleneck tests for detecting recent population declines. Mol. Ecol. 2012, 21, 3403-3418. [CrossRef] [PubMed]

181. Frankham, R.; Ballou, J.D.; Ralls, K.; Eldridge, M.D.B.; Dudash, M.R.; Fenster, C.B.; Lacy, R.C.; Sunnucks, P. Genetic Management of Fragmented Animal and Plant Populations; Oxford University Press: Oxford, UK, 2017. 
182. Hale, M.L.; Burg, T.M.; Steeves, T.E. Sampling for microsatellite-based population genetic studies: 25 to 30 individuals per population is enough to accurately estimate allele frequencies. PLOS ONE 2012, 7, e45170. [CrossRef] [PubMed]

183. Jeffries, D.L.; Copp, G.H.; Handley, L.L.; Olsén, H.K.; Sayer, C.D.; Hänfling, B. Comparing RADseq and microsatellites to infer complex phylogeographic patterns, an empirical perspective in the Crucian carp, Carassius carassius, L. Biol. Invasions 2016, 25, 2997-3018. [CrossRef] [PubMed]

184. De Jongh, A.W.J.J.; Tokar, G.A.; Matvyeyev, A.S.; de Jong, T.; de Jongh-Nesterko, L.V. European mink (Mustela lutreola) still surviving in Ukrainian deltas of the Danube and Dniester. Lutra 2007, 50, 33-36.

185. Maran, T.; Skumatov, D. Captive breeding and reintroductions-Russia. Eur. Mink Conserv. Actvities Eur. Newsl. 2017, 2017, 6.

186. Skorupski, J.; Polish Society for Conservation Genetics LUTREOLA, Szczecin, Poland. Personal Communication, 2020.

187. Polish Society for Conservation Genetics LUTREOLA. Available online: http://lutreola.pl/aktualnosci/1/31szy-marca-dniem-norki-europejskiej/ (accessed on 15 September 2020).

Publisher's Note: MDPI stays neutral with regard to jurisdictional claims in published maps and institutional affiliations.

(C) 2020 by the author. Licensee MDPI, Basel, Switzerland. This article is an open access article distributed under the terms and conditions of the Creative Commons Attribution (CC BY) license (http://creativecommons.org/licenses/by/4.0/). 